Hydrol. Earth Syst. Sci. Discuss., 6, 6207-6246, 2009 www.hydrol-earth-syst-sci-discuss.net/6/6207/2009/ (C) Author(s) 2009. This work is distributed under the Creative Commons Attribution 3.0 License.
Hydrology and Earth System Sciences Discussions

Papers published in Hydrology and Earth System Sciences Discussions are under open-access review for the journal Hydrology and Earth System Sciences

\title{
Assessing the added value of high-resolution isotope tracer data in rainfall-runoff modelling
}

\section{Birkel ${ }^{1,2}$, S. M. Dunn ${ }^{1}$, D. Tetzlaff ${ }^{2}$, and C. Soulsby ${ }^{2}$}

${ }^{1}$ The Macaulay Land Use Research Institute, Craigiebuckler, Aberdeen, AB15 8QH, UK

${ }^{2}$ Northern Rivers Institute, School of Geosciences, University of Aberdeen, Aberdeen AB24 3UF, Scotland, UK

Received: 10 September 2009 - Accepted: 16 September 2009 - Published: 1 October 2009 Correspondence to: C. Birkel (c.birkel@ macaulay.ac.uk)

Published by Copernicus Publications on behalf of the European Geosciences Union.

\section{HESSD}

6, 6207-6246, 2009

Assessing the added value of

high-resolution isotope tracer data

C. Birkel et al.

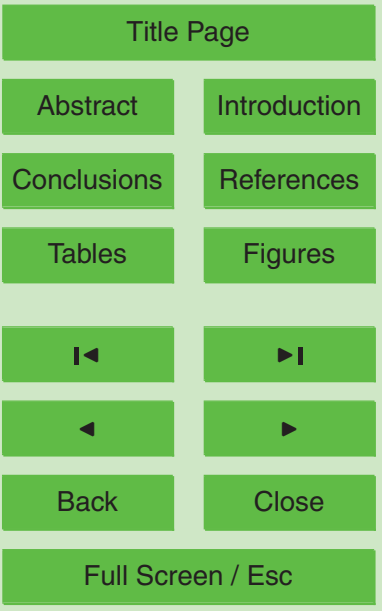

Printer-friendly Version

Interactive Discussion 


\section{Abstract}

A study has been undertaken in a small agricultural catchment in east Scotland with the objective of assessing the value of high-resolution isotope data for integration within hydrological models. Daily samples of precipitation and stream flow, collected over a

5 year, have been analyzed for deuterium content using new laser spectroscopy technology. This study set out to evaluate whether the utility of such high-resolution isotope data outweighs the associated uncertainty, as well as uncertainty in discharge measurements. A multi-criteria approach was used to evaluate the simulation of two independent objective functions - stream flow and stream deuterium - against model and data errors. Particular emphasis was placed on different input and output sampling resolutions. The data indicate that moderate isotopic variability in the stream response between rainfall events, which is not captured using weekly tracer data, has little influence on model performance. In contrast, the input resolution of precipitation deuterium concentrations, which were much more variable, proved to be crucial. A low-parameterized

15 Catchment Isotope Model (CIM) was developed and adequately reflects flow dynamics and deuterium peaks, but a simple assumption of "good-mixing" in the isotope module is not able to fully reproduce the daily stream deuterium dynamic. Multi-criteria evaluation, however, significantly constrained acceptable behavioural parameter sets and therefore reduced the model's degree of freedom. This approach has provided further assessment of the value of tracers in hydrological modelling, demonstrating their usefulness in terms of model conceptualization, development and calibration, which outweighs the additional parameter and measurement uncertainty.

\section{Introduction}

Considerable uncertainty surrounds the prediction of hydrological responses of catchment systems to land use and climate change (Ivanovic and Freer, 2009). A major limitation in understanding catchment behaviour is the difficulty of adequately charac-

\section{HESSD}

6, 6207-6246, 2009

Assessing the added value of

high-resolution isotope tracer data

C. Birkel et al.

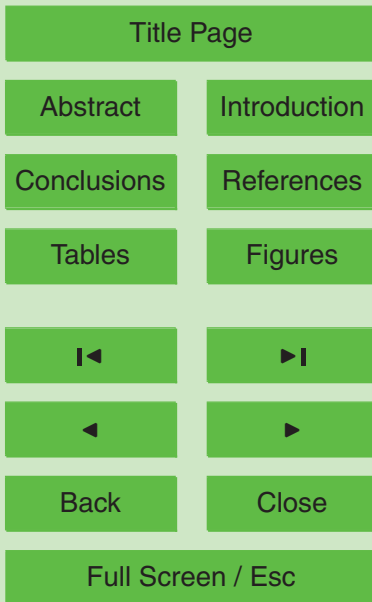

Printer-friendly Version

Interactive Discussion 
terizing hydrological flow pathways, storage-discharge relationships, water residence times, mixing processes and their interactions with the biosphere. This leads to high predictive uncertainty in hydrological modelling (Beven, 2006), which has also important implications for modelling and predicting water quality changes resulting from envi5 ronmental changes. Recent technological developments have potential in tackling the challenge of more adequately characterizing the hydrological processes in catchments through the provision of new and higher resolution data sets (Tetzlaff et al., 2007a; Soulsby et al., 2008). Conservative tracers have proven utility in understanding water and solute fluxes due to their integrative nature which helps overcome the variability 10 of hydrometric point measurements (Soulsby et al., 2000, 2003; Soulsby and Tetzlaff, 2008; Dunn and Bacon, 2008). Since e.g. Herzer and Kinzelbach (1987) linked water and solute fluxes in hydrological modelling to simulate pollutant transport, the mixingcell concept has been adapted in conceptual models to identify parameter values and to verify internal model function (de Grosbois et al., 1988). Geochemical tracer integration into models - as an additional objective function - has also been shown to help improve calibration and constrain behavioural parameter sets (Birkel et al., 2009). However, stable isotopes of water have been mainly used in lumped parameter models to study mean transit times (Malozcewski and Zuber, 1982). More recent work has implemented stable isotopes into conceptual models (Stadnyk et al., 2005), but sim20 ulations have been shown to depend heavily on the sampling resolution (Dunn et al., 2008b).

In recent years, laser spectroscopy has opened possibilities for providing high temporal resolution isotope data with a significant reduction in analysis costs (Lyon et al., 2009). Previous studies have used higher resolution isotope data focusing on single events (e.g. Weiler et al., 2003; Wissmeier and Uhlenbrook, 2007), but these have limitations for representing the longer term context of mixing processes required to underpin modelling. Stable isotopes can provide invaluable insights into mixing processes, hydrological flow paths, residence times and solute transport (e.g. Soulsby et al., 2006; Tetzlaff et al., 2007b; Tetzlaff and Soulsby, 2008; Turner et al., 2006). How-

\section{HESSD}

$6,6207-6246,2009$

Assessing the added value of

high-resolution isotope tracer data

C. Birkel et al.

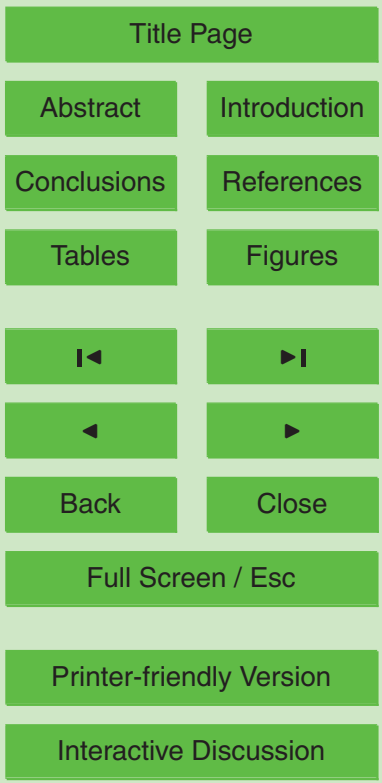


ever, the added value of stable isotopes in hydrological modelling studies remains still uncertain mainly due to the fact that high resolution isotope data for longer time periods were not available (Dunn et al., 2008b).

In discussions about uncertainty in model applications (Pappenberger and Beven, 5 2006), the potential significance of measurement errors has recently received more attention. Work by Harmel et al. (2006) assessed the importance of measurement errors in discharge observations and water quality studies; suggesting direct inclusion of measurement errors in model evaluation (Harmel et al., 2007). Similarly, Liu et al. (2009) suggested an approach towards defining the limits of acceptability in measure10 ment errors. This supports the need to account for data errors in a diagnostic model evaluation as proposed by Gupta et al. (2008). Recent studies have acknowledged the additional uncertainty incorporating isotope data in hydrological modelling (Fenicia et al., 2008b), but do not fully account for the errors and consequences for model calibration and evaluation.

This study was undertaken to examine the value of high-resolution isotope time series for the conceptualization, calibration and evaluation of simple, low-parameterized hydrological models. A particular focus was to account for the errors and uncertainties associated with the fundamental data used in the modelling analysis of isotope variability in precipitation and streamflow. The study had three specific objectives:

1. To generate a high-resolution data set of deuterium in daily precipitation and streamflow.

2. To conceptualize and develop a simple, low-parameterized flow-tracer model suitable for simulating water and isotope fluxes.

3. To assess the importance of sampling resolution on the utility of incorporating tracers in the modelling process.

4. To evaluate the advantages of incorporating high resolution isotope data in simple, multi-calibrated conceptual flow-tracer models relative to measurement errors.
HESSD

6, 6207-6246, 2009

Assessing the added value of

high-resolution isotope tracer data

C. Birkel et al.

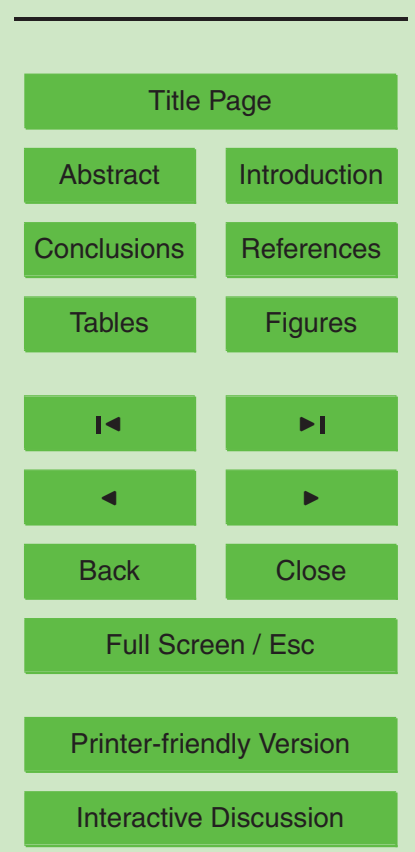




\section{Study site}

The study was based in the $2.3 \mathrm{~km}^{2}$ Wemyss catchment, which is drained by the Baldardo burn, a tributary of the Lunan Water in north-east Scotland (Fig. 1). Annual average precipitation is estimated at around $820 \mathrm{~mm}$, this is generated mainly by At5 lantic air masses with highest monthly precipitation in October $(120 \mathrm{~mm})$ and lowest in July $(40 \mathrm{~mm})$. Annual discharge (2008-2009) at Wemyss is $238 \mathrm{~mm}$. The difference includes evapotranspiration, plus leakage to deeper groundwater in a regional aquifer (see below). The Wemyss sub-catchment is underlain by Old Red Sandstone of Devonian age, which forms part of a highly productive aquifer (Ó Dochartaigh, 2004).

10 The aquifer is vulnerable to pollution from land use as it is overlain by relatively freely draining podzols, which mainly contribute to groundwater recharge (Table 1). However, around $30 \%$ of these soils show gley characteristics indirectly impeding drainage. These areas facilitate the generation of quickly flowing surface and near-surface runoff processes (Dunn et al., 2009). Intense agricultural activities (87\%), such as crops 15 and livestock (Fig. 1), have resulted in soil under-drainage and a significant number of drainage ditches where soils are prone to water-logging and these are likely to form an important runoff generation mechanism for peak flows (SEPA, 2005).

\section{Data}

\subsection{Hydrological data}

Discharge (15 min resolution) was continuously measured at a natural rated section of the Baldardo Burn and the Lunan Water at Kirkton Mill (KM). At Wemyss, mean stream velocities measured with an ISCO 740 area-velocity flowmeter were used to calibrate a rating curve. Monitoring over the duration of the study (1 May 2008-31 May 2009) indicated that the water balance at Wemyss is not closed presumably due to a significant amount of leakage to regional groundwater recharge $\left(>100 \mathrm{~mm} \mathrm{a}^{-1}\right)$.

\section{HESSD}

6, 6207-6246, 2009

Assessing the added value of

high-resolution isotope tracer data

C. Birkel et al.

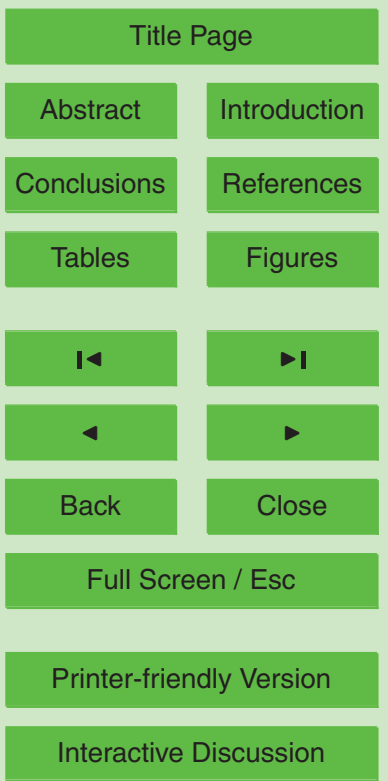


Precipitation data were derived from daily observations from a station located at Forfar (5 km from catchment) and a tipping bucket gauge (Campbell) located at the Wemyss study site. The evapotranspiration ET was estimated according to Dunn and Mackay (1995) using data from a meteorological station located close to the catchment at an 5 altitude of $\mathbf{3 0 0}$ ma.s.I. Although, this may slightly underestimate ET for the lowland site at Wemyss, the energy balance is rather constant in the east of Scotland and the estimates were deemed reasonable. The data were summed to daily averages for this study.

\subsection{Isotope data base}

10 Daily streamflow and precipitation samples (Fig. 2) have been collected for stable isotope analysis using ISCO automatic samplers since April 2008. Paraffin oil was applied to the sample bottles to avoid evaporation losses (IAEA, 2009). In order to interpret sources of error and to facilitate statistical analysis, weekly stream grab samples were also collected. For precipitation, daily samples were accumulated over $24 \mathrm{~h}$, while the stream samples were composites of four equal samples taken at six-hourly intervals. The deuterium $\left({ }^{2} \mathrm{H} /{ }^{1} \mathrm{H}\right)$ and oxygen-18 $\left({ }^{18} \mathrm{O} /{ }^{16} \mathrm{O}\right)$ ratios are simultaneously determined with a Los Gatos Research (LGR) DLT-100 laser diode water isotope analyzer and transformed into the $\delta$-notion $\left(\delta^{2} \mathrm{H}\right.$ and $\delta^{18} \mathrm{O}$ in \%) according to VSMOW standards. Due to the inter-dependence of both isotopes our analysis focuses on deuterium. Dur20 ing analysis a standard analytical protocol was applied, as recommended by Lis et al. (2008). At the beginning and end of each analyzer run (54 samples) a range of five working standards is used to set up the calibration and to monitor accuracy and precision. Additionally, after every fifth unknown and unfiltered sample, a single standard is placed to monitor and correct for any drift occurring. The samples are injected five 25 times consecutively and the average of the two last is taken into account for analysis. An artificial weekly time series of the precipitation input $\left(C_{\text {in }}\right)$ was also constructed from

\section{HESSD}

6, 6207-6246, 2009

Assessing the added value of

high-resolution isotope tracer data

C. Birkel et al.

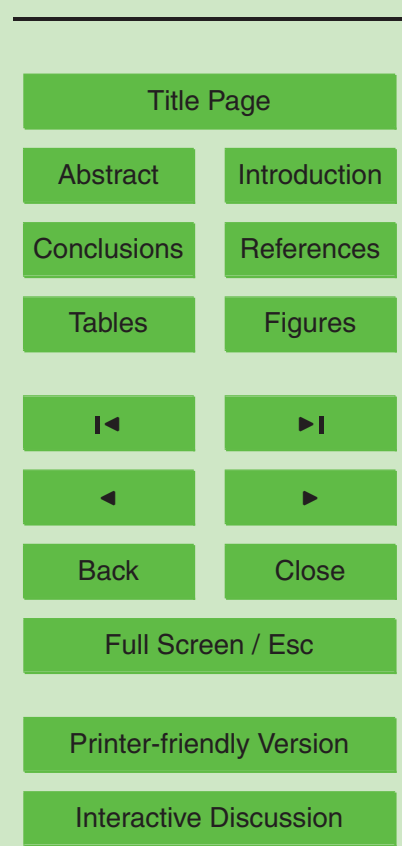


the available daily samples by applying a volume weighting function:

$C_{\text {in }}\left(t_{i}\right)=\frac{\sum_{i=1}^{N} \delta_{i} * P_{i}}{\sum_{i=1}^{N} P_{i}}$

Where $N$ is the number of single sampling events in regular time steps during the whole observation period, $P_{i}$ and $\delta_{i}$ are precipitation rates of a single event and its isotope 5 content, respectively. The daily record was then updated with the volume weighted mean, in order to mimic weekly and bi-weekly recollection of rain bulk samples and the level of commonly available data (e.g. Dunn et al., 2008b).

\section{Methodology}

\subsection{Statistical methods}

10 The $\delta^{2} \mathrm{H}$ time series were summarized using basic statistic descriptors such as mean, maximum, minimum, standard deviation (Std. Dev.) and the 10th and 90th percentile to compare different sampling resolutions. In addition, the skewness and kurtosis were examined to assess differences in sampling collection method. In terms of assessing the significance of measurement uncertainty in the modelling process, the accuracy of discharge measurements (Di Baldassarre and Montanari, 2009) and stable isotope sampling and analysis were assumed to be the largest potential source of error. This is reasonable given the uniformity of precipitation and evapotranspiration in this small catchment with limited variation in relief. The measurement uncertainty of discharge and stable isotope data was assessed applying the Root Mean Square Error propaga-

tion method (RMSE, Eq. 2). The total potential Error $\left(E_{p}\right)$ incorporates the sampling method, analytical method and sample preservation for stable isotopes and the rat-

HESSD

6, 6207-6246, 2009

Assessing the added value of

high-resolution isotope tracer data

C. Birkel et al.

\section{Title Page}

Abstract Introduction

Conclusions References

Tables Figures

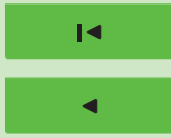

$\rightarrow$ I

Back

Close

Full Screen / Esc

Printer-friendly Version

Interactive Discussion 
ing curve, streambed condition, individual streamflow measurements and continuous stage measurement uncertainty for discharge observations (Harmel et al., 2006):

HESSD

$E_{p}=\sqrt{\sum_{i=1}^{n}\left(E_{1}^{2}+E_{2}^{2}+\ldots E_{n}^{2}\right)}$

The upper $\left(\mathrm{UB}_{i}(u)\right)$ and lower $\left(\mathrm{UB}_{i}(/)\right)$ measurement uncertainty boundaries for $E_{p}$ are 5 calculated (Harmel et al., 2009) and then applied to the model output (observation $O_{i}$ ) for model calibration and analysis (Eq. 3):

$\mathrm{UB}_{i}(u)=O_{i}+\frac{E_{p}}{100} * O_{i} \quad \mid \quad \operatorname{UB}_{i}(I)=O_{i}-\frac{E_{p}}{100} * O_{i}$

\subsection{Modelling approach}

\subsubsection{Model concept}

10 A simple rainfall-runoff model, the Catchment Isotope Model (CIM), was developed to examine the value of incorporate tracers and to assess the significance of errors and uncertainties in the data (Fig. 3 and Table 2). The model is based on rainfall-runoff relationships using three parameters in two parallel reservoirs, where in each $Q=S / k$ (linear scaling parameter $k$, storage $S$ and discharge $Q$ ). These are used to route any conservative tracer through the catchment (Hooper et al., 1988) assuming that solutes fully mix within each of the two storage compartments. The following equation (Eq. 4) mathematically expresses the link of water and tracer fluxes in the applied mixing cell approach (Herzer and Kinzelbach, 1987):

$\frac{\Delta N}{N * \Delta t}=\frac{\Delta V}{V * \Delta t}$

20 with $V$ being the volume of water in the storage $(\mathrm{mm}), \Delta V / \Delta t$ the water flux per time step $\Delta t\left(\mathrm{~mm} \mathrm{~d}^{-1}\right), N$ the amount of tracer and $\Delta N / \Delta t$ the solute flux per time step 6214

Assessing the added value of

high-resolution isotope tracer data

C. Birkel et al.

\section{Title Page}

Abstract Introduction

Conclusions References

Tables Figures

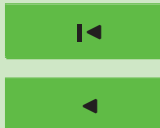

Back

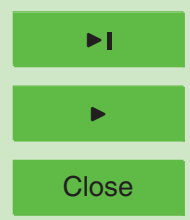

Full Screen / Esc

Printer-friendly Version

Interactive Discussion 
$\Delta t\left(\right.$ flux $\left.\mathrm{d}^{-1}\right)$. Thus, the solute module is fully dependent on the parameterization and calibration of the water flux model. The upper storage $S_{\text {up }}$ is not restricted to a lower limit; sub-zero values indicate that the storage is emptied by transpiration and does not generate any lateral flow. This allows threshold-like behaviour to be captured by the 5 model (Fenicia et al., 2008b). Due to the high turn over of storage in the flow model, the two storage parameters $S_{M V}$ (upper mixing volume), $V_{M V}$ (lower mixing volume) are introduced into the isotope module (Barnes and Bonell, 1996) to account for an additional mixing volume (immobile water) in the catchment system (Fig. 3, Table 3) resulting in a 5-parameter version of the CIM model.

10 The unclosed nature of the water balance in the Wemyss catchment raises the question of leakage from the superficial catchment to the deeper sub-surface, which we acknowledge by an additional loss parameter GWloss (Eq. 7) to account for a regional groundwater recharge (6-parameter model). The value of an additional parameter $c$ to conceptualize a preferential direct runoff generation component $Q_{\text {direct }}(t)$ (Leaney et al., 1993) was also explored (7-parameter model). This mechanism allows direct mixing of rain with stream water, even when the upper storage is not activated. The water and tracer components $(Q, P, \mathrm{ET}, S, V)$ are subdivided into upper, up, and lower, $I$, compartments. Total runoff is the sum of the discharge of both upper and lower storage, whereas the simulated stream tracer concentration is calculated via a weighted 20 mean of storage outflow and concentration (Eq. 15). Input time series are looped over 5 years to establish initial conditions and to verify the internal water balance. All water balance components are quantified in $\mathrm{mm} \mathrm{d}^{-1}$ and all isotope concentrations in \%o.

\subsubsection{Model application: sensitivity, calibration and evaluation under uncer- tainty}

25 A stepwise, multi-criteria calibration (Khu et al., 2008) was used to evaluate the behaviour of the model and the added value of isotope data. The procedure can be summarized as follows:

HESSD

6, 6207-6246, 2009

Assessing the added value of

high-resolution isotope tracer data

C. Birkel et al.

\section{Title Page}

Abstract Introduction

Conclusions

Tables

References

Figures

14

4

Back

Full Screen / Esc

Printer-friendly Version

Interactive Discussion 
1. Monte Carlo (MC) random sampling with 10000 iterations was used to assign parameter values to model simulations.

HESSD

2. A subjective sensitivity analysis was applied to all parameters to define efficiency criteria thresholds taking into account measurement uncertainty.

3. The discharge objective function thresholds using different performance criteria (multi-criteria modes) are then used to calibrate the flow model over a second 10000 iteration MC phase.

4. Finally, the calibration (10000 iterations) of the flow-tracer CIM model uses both the discharge $(Q)$ and the independent deuterium $\left(\delta^{2} H\right)$ (multi-criteria measures) in evaluation according to the efficiency criteria thresholds.

As different performance criteria differ in their treatment of bias and extreme values, their suitability for evaluating different objective functions varies. Thus, for evaluation of the CIM model; the Nash-Sutcliffe (NS) efficiency (Nash and Sutcliffe, 1970), volumetric error VE criteria (Criss and Winston, 2008) and Root Mean Square Error RMSE

were used as objective functions for simulation of discharge and isotope content. The NS and RMSE criteria are biased towards evaluation of extreme values, whereas the VE measure is more objective at evaluating the system dynamics. Applying the accepted behavioural parameter sets to the model allows model uncertainty boundaries to be established.

20 We adapted the simple methodology of Harmel et al. (2006) to integrate the total probable error range of measured data directly into the model calibration and evaluation procedure. The traditional error term $E_{i}=O_{i}-P_{i}$ used in performance criteria determines the deviation of predicted $P_{i}$ from observed $O_{i}$ values. This was substituted by the uncertainty error term $\mathrm{EU}_{i}=\mathrm{UO}_{i}(u, l)-P_{i}$ for calculating the VE, NS and RMSE, which defines the deviation as the difference between the predicted data and the upper and lower uncertainty limits $\left(U O_{i}(u, I)\right.$, Eq. 3). For predicted values that lie within the uncertainty boundaries, the modified deviation $\mathrm{EU}_{i}$ is set equal to zero. For predicted
6, 6207-6246, 2009

Assessing the added value of

high-resolution isotope tracer data

C. Birkel et al.

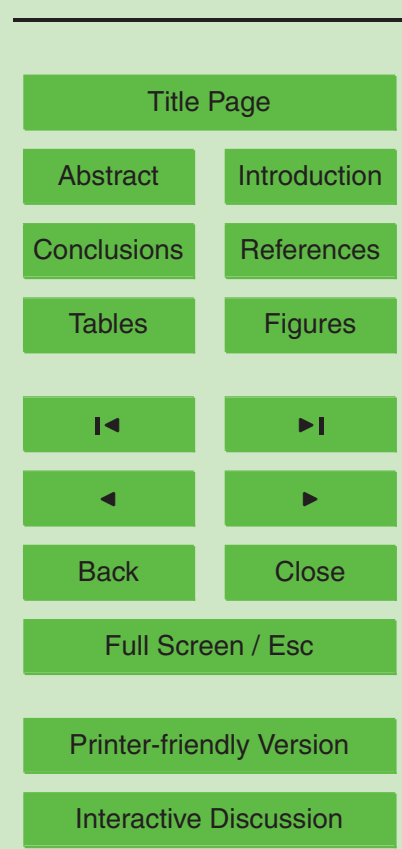


data points that lie outside the uncertainty limits, the error estimate is minimized for each measured and predicted data pair. This allows the value of additional data as objective functions for model calibration to be assessed in the context of measurement uncertainty. As it gives equal value to all predictions that fall between the broader limits 5 of the observed data, the method results in higher values of the efficiency terms than would be achieved through simple calibration to the observed data.

\section{Results}

\subsection{Isotope response to hydrological variability}

Over the 13 month study period 1 May 2008-31 May 2009, we observed slightly drier 10 conditions than average, resulting in the Baldardo burn falling dry during one week in July 2008 following a dry spring (Fig. 2). The late summer was wetter and precipitation was greatest between December and February 2009. Drier conditions followed on in spring. In general, stream isotopes reflect precipitation variability and seasonality albeit in a damped manner. Precipitation with an enriched positive isotopic content was

characteristic of summer 2008, and more depleted signatures were observed during the winter (Fig. 2). Highest positive stream deuterium signatures can be observed for small events in the low flow period in May 2008. Heavy winter storms cause a reversal of in stream deuterium signatures to more negative values and the most notable isotope characteristics are expressed in events (December to February). During this time

\subsection{Assessment of different sampling resolutions and methods}

Table 3 summarizes the statistics of the isotope data for both daily and weekly samples. The broader data range, in terms of extreme values, is captured by the daily stream samples, though comparable mean values and percentiles were observed for

\section{HESSD}

6, 6207-6246, 2009

Assessing the added value of

high-resolution isotope tracer data

C. Birkel et al.

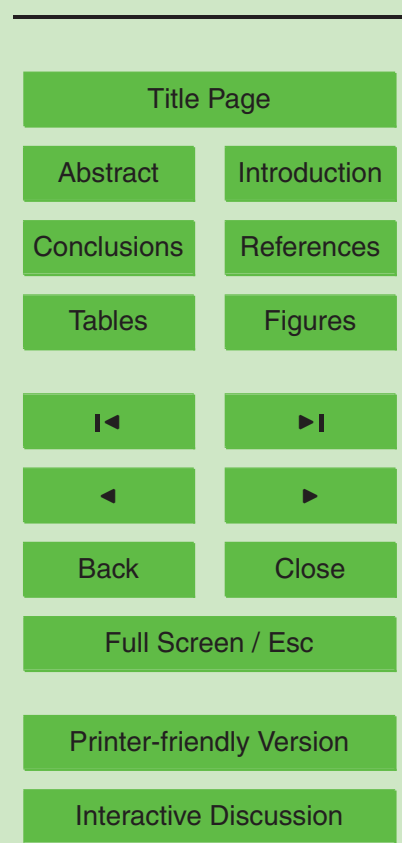


both methods. From these differences it would be reasonable to expect that the sampling resolution will have important implications for modelling, especially when the input function forces the simulation of stream isotopes. The data suggest the difference in sampling resolution will be most important for precipitation because of the greater 5 temporal variability. It is also notable that the mean streamflow deuterium is not in equilibrium with the mean precipitation value over the duration of the sampling record (Table 3).

With regards to the sampling methods, the statistical differences between weekly spot samples and the mean daily composite sample for streamwater were surprisingly similar for their mean isotope composition, standard deviation, percentiles, extreme values and skew (Table 4). However, a higher kurtosis for the grab samples indicated a higher number of samples close to the mean value reflecting composite samples better represent average isotopic conditions rather than at only one point in time.

\subsection{Model conceptualization, development and evaluation under uncertainty}

\subsubsection{Discharge and isotope data uncertainty}

We based our estimates of uncertainty in discharge measurements on evaluation of our data and literature values (Harmel et al., 2006). This resulted in an assumed $\pm 10 \%$ uncertainty in the rating curve, $\pm 8.5 \%$ error in the manual measurements of velocity and depth, an additional $\pm 10 \%$ error due to varying streambed conditions and $\pm 0.035 \%$

error for automatic stage recording. These errors propagate to a total potential error of $E_{p}= \pm 16.5 \%$, which is used to calculate discharge uncertainty boundaries according to Eq. (3).

The uncertainty of measured deuterium isotopes in precipitation and stream water was estimated by taking the mean analytical measurement error for all runs $(0.72 \%$ o) ence in standard deviation $\left(\delta^{2} \mathrm{H}= \pm 0.12\right)$ between weekly composite and grab samples (Table 4). There was no evidence of evaporation in the field-stored sample bottles,

HESSD

6, 6207-6246, 2009

Assessing the added value of

high-resolution isotope tracer data

C. Birkel et al.

\section{Title Page}

Abstract Introduction

Conclusions

Tables

References

Figures

14

4

Back

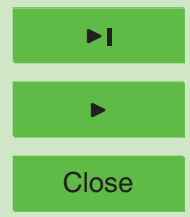

Full Screen / Esc

Printer-friendly Version

Interactive Discussion 
though for occasional small sample volumes at the rain sampler and during warm weather direct evaporation from the gauge orifice, and associated fractionation, may occur with limited enrichment. We account for potential evaporation losses in the sample bottle with an estimated sample preservation error of \pm 0.5 for $\delta^{2} \mathrm{H}$. This gives

5 a combined potential isotope measurement error of $E_{p}= \pm 3 \%$ for $\delta^{2} \mathrm{H}$ data used to calculate uncertainty boundaries.

\subsubsection{Iterative model development with consideration of uncertainty}

The modelling procedure adopted in the application of CIM compared three differently parameterized conceptual models (Fig. 4). As shown in Fig. 3, these were a basic

10 5-parameter model, a 6-parameter model (accounting for deeper leakage) and a 7parameter model (allowing a proportion of precipitation to remain unmixed). A summary of the results is given in Table 5, which shows the maximum values of the performance measures achieved for each model; these already include measurement uncertainty. As expected the 5-parameter model had the poorest performance statistics 15 (Q_NS=0.72, Q_VE=0.51) over- and underestimating high- and low flow periods, respectively. By including the regional groundwater recharge (loss parameter - GWloss) in the 6-parameter model, the simulation of the hydrodynamics substantially improved (Q_NS $=0.86$ and $\left.Q_{-} V E=0.64\right)$. The deuterium simulation of both models showed differences that were much more subtle. The general dynamic of the ${ }^{2} \mathrm{H}$ response was 20 captured, but not the detail (Fig. 4b). However, further improvement was achieved by including the direct runoff component in the 7-parameter model. The addition of this preferential flow parameter resulted little improvement to discharge simulations, but significantly increased the performance of the isotope module (D_NS $=0.45$ vs. 0.54 ).

As a result of this step-wise development, the 7-parameter CIM model was used for 25 testing parameter sensitivity and the effect of sampling resolution on isotope simulation. Generally, the hydrodynamics were simulated satisfactorily by the model (Fig. 4a). The daily deuterium stream signal shows fine scale variability during recessions and high flows, which are not captured by the model. The measurement uncertainty bands

\section{HESSD}

6, 6207-6246, 2009

Assessing the added value of

high-resolution isotope tracer data

C. Birkel et al.

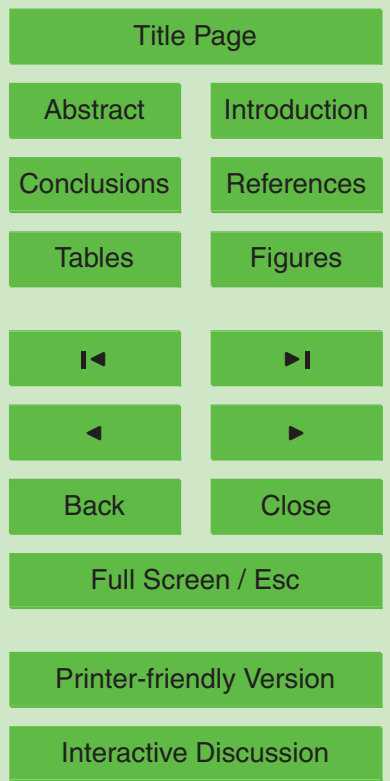


suggest the fine scale variability in measured isotope dynamics is real rather than just measurement error. The model damps out this variability, especially where no input occurs. However, most measured isotope extremes and the general dynamics were reflected in the simulation. Figure 5 compares the measurement uncertainties with 5 the uncertainties in the simulations. The estimated CIM model uncertainty mostly lies in between the designated discharge and deuterium measurement uncertainty, except for low flow and recession periods and the following rewetting phase. Although, model uncertainty outweighs the uncertainty associated with measured data during these periods, it can be seen that the estimated measurement uncertainty is an important 10 source of error.

\subsubsection{Comparing parameter sensitivity and model calibration against measure- ment errors}

The parameter sensitivity was evaluated after $10000 \mathrm{MC}$ iterations. All five flow module parameters $\left(k_{1}, k_{2}, R, c\right.$ and GWloss) facilitated the subjective definition of efficiency criteria thresholds (indicated by lines in Figs. 6 and 7) whose exceedance is accepted as behavioural. The discharge $Q$ thresholds for calibration (incorporating measurement uncertainty) were set to Q_VE $>0.65$; Q_NS was set to exceed 0.85 and Q_RMSE below $0.35 \mathrm{~mm}$. In addition, the deuterium (D) volumetric error D_VE $>0.975$, D_NS $>0.5$ and D_RMSE $<2.15$ were defined as behavioural tracer thresholds. The least sensi20 tive parameter accounts for regional groundwater recharge (GWloss) ranging from 0.1 to $0.8 \mathrm{~d}^{-1}$, whereas the recharge rate parameter $(R)$ is very sensitive with a narrow interval from 0.1 to $0.42 \mathrm{~d}^{-1}$. The direct effect of model evaluation against estimated measurement errors (uncertain parameter space - grey cubes) can be seen in Figs. 6 and 7 , respectively. The flow module performance measures increased about $20 \%$ in average, whereas the isotope module efficiencies increased up to $100 \%$.

At first sight, the parameter space for both isotope mixing volumes $\left(S_{M V}, V_{M V}\right)$ (Fig. 7) looks rather insensitive compared to the flow parameters. However, the upper mixing volume $\left(S_{M V}\right)$ slightly decreased towards the maximum sampling limit of $1000 \mathrm{~mm}$,
HESSD

6, 6207-6246, 2009

Assessing the added value of

high-resolution isotope tracer data

C. Birkel et al.

Title Page

Abstract Introduction

Conclusions

Tables

References

Figures

14

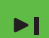

4

Back

Close

Full Screen / Esc

Printer-friendly Version

Interactive Discussion 
whereas the lower mixing volume $\left(V_{M V}\right)$ shows contrary behaviour. For both parameters, a minimum initial volume is required to exceed the defined threshold values $\left(S_{M V}>50 \mathrm{~mm}\right.$ and $\left.V_{M V}>150 \mathrm{~mm}\right)$, which confirms the necessity of additional mixing volumes to adequately simulate stream deuterium signals. Despite the broad range of 5 equally acceptable behavioural parameter sets and associated equifinality, the results for both parameter intervals are clearly separated (Table 6). The $S_{M V}$ interval ends at $450 \mathrm{~mm}$ before the lower mixing volume starts at $500 \mathrm{~mm}$. The multi-criteria calibrated parameters satisfy the efficiency criteria thresholds, but do not reach the maximum values (Fig. 7 - black circles). Note that the volumetric error criterion appears to be very insensitive with only minimal changes in the parameter space.

The calibration of the flow module (multi-modes calibration - black triangles above threshold in Fig. 6) determined by discharge efficiency criteria thresholds (Q_NS, Q_VE, and Q_RMSE) resulted in 445 behavioural parameter sets from 10000 random model runs. The calibration of the CIM model (multi-criteria calibration - grey circles above threshold in Figs. 6 and 7), which satisfied the criteria for simulation of flow and deuterium resulted in 24 behavioural parameter sets. This significantly constrained the intervals of behavioural parameter values (Table 6).

\subsubsection{The effect of input forcing on tracer simulation}

The multi-criteria calibrated 7-parameter CIM model clearly shows that model perfor-

mance decreases with increasing sampling interval (Table 7). Considering the model simplicity, which is relatively insensitive to the daily isotope variability in streamflow, the decline in performance appears quite substantial. NS for deuterium decreased from a value of 0.54 (daily input) to 0.45 (bi-weekly data). Figure 8 shows the most obvious differences, which occurs simulating extreme values (e.g. in January 2009). In this 25 case, weekly or bi-weekly sampling resolutions require many precipitation events to be updated with the weighted mean isotope value (note that in Fig. 8 the size of circles corresponds to precipitation volume). This updating procedure averages out extreme events. The stream isotope signature simulated during recession and low flow periods,
HESSD

6, 6207-6246, 2009

Assessing the added value of

high-resolution isotope tracer data

C. Birkel et al.

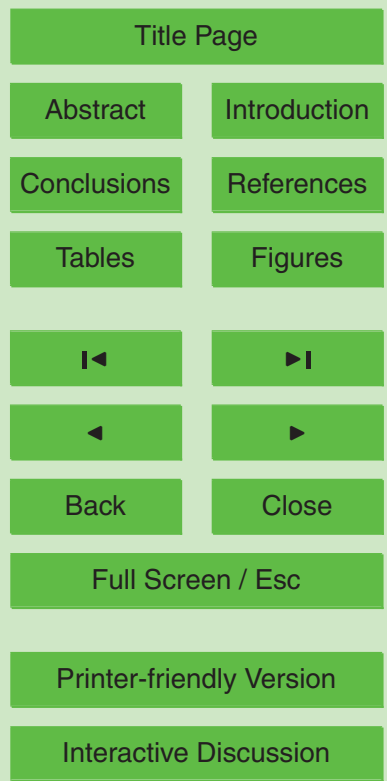


when the lower storage dominated, appears unaffected by the different input function resolutions due to relatively high mixing volumes in the storage system.

\section{Discussion}

\subsection{The effect of isotope sample resolution on modelling}

5 The more variability that is observed in isotopic stream signatures, the higher the sampling resolution should be to inform model concepts (Soulsby et al., 2008). In wellmixed systems such as Maimai (e.g. Pearce et al., 1986), where tracer dynamics in streamflow are generally treated as "event-based" (Fenicia et al., 2008b), sample resolution may play a minor role as long as major events are captured (Dunn et al., 2008b). 10 This has implications for field data collection, instrumentation and for high-resolution sampling campaigns (Moss, 1979; Fenicia et al., 2008b). The CIM model calibrated against weekly data (not shown here) performs slightly better $(10 \%)$ than applied to daily data due to an averaging of the isotope dynamics in stream water. However, the results for both daily and weekly isotope data are very similar and suggest that 15 multi-criteria calibration can be successfully applied to our data regardless of sampling resolution. However, we hypothesized that daily measurements of the isotope content of precipitation would improve daily model simulations. This was confirmed by comparing daily, weekly and bi-weekly input functions on model performance (Table 7). The importance of input data resolution on model performance can be compared to the importance of model conceptualization. For example, including a preferential flow path conceptualization into the model structure (Leaney et al., 1993) resulted in a similar performance improvement (Table 5) as applying a finer input sampling resolution from bi-weekly to daily (Dunn et al., 2008a).

\section{HESSD}

$6,6207-6246,2009$

\section{Assessing the added value of \\ high-resolution isotope tracer data \\ C. Birkel et al.}

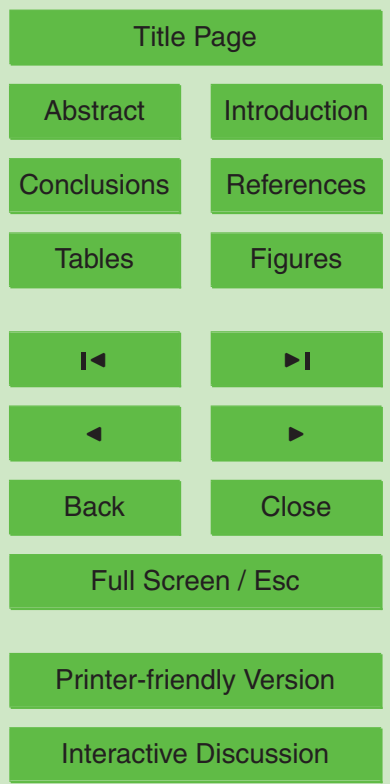




\subsection{Uncertainties involved in deuterium simulation}

Both storages in CIM conceptualize soil and till layers contributing to in-stream mixing and successfully simulate general tracer dynamics and extremes. Due to the unclosed water balance and regional groundwater recharge in the Wemyss catchment, it cannot 5 yet be established whether, or the extent to which, deep groundwater from the underlying sandstone aquifers contributes to mixing (Dunn and Bacon, 2008). However, although the daily isotope record aided the conceptualization of a preferential flow path (Weiler and McDonnell, 2007), to represent important changes in stream isotopic signature, much of the uncertainty in simulated discharge and deuterium (Fig. 5) is caused by over-simplistic model assumptions. CIM is not able to account for important between precipitation event variability (McDonnell et al., 1991) as observed in the daily data record. Especially during low flow periods the isotopic signature in discharge might be affected by in-stream biogeochemical processes causing fractionation. Furthermore, interaction between the unsaturated and saturated zones (Seibert et al., 2003; Birkel et al., 2009) resulting in mass transfer between mobile/immobile domains (Simic and Destouni, 1999) is neglected. Due to mass movement, soils tend to be thinner on the hilltops and thicker on the mid and lower slopes in the Wemyss catchment suggesting spatially variable transmissivity (Sayama and McDonnell, 2009). This most likely distributes processes in vertical and downslope dimensions, thus affecting water ages 20 (Stewart and McDonnell, 1991). The interaction of mixing processes in time and space is also not considered (Katsuyama et al., 2009). Therefore, potential areas to improve deuterium simulations are the underlying assumptions of solute mixing in terms of the sub-surface volumes and processes that are involved (McGuire et al., 2006).

\subsection{Measurement uncertainty of discharge and isotope data}

25 The total estimated RMSE error of $16.5 \%$ for measured discharge data using the rating curve method is low compared to other studies by e.g. Di Baldassarre and Montanari (2009). This may simply reflect the small and relatively stable channel section.
HESSD

6, 6207-6246, 2009

Assessing the added value of

high-resolution isotope tracer data

C. Birkel et al.

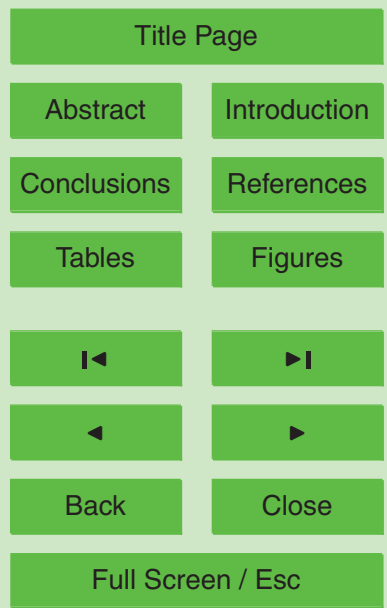

Printer-friendly Version

Interactive Discussion 
However, accounting for higher measurement uncertainties under low and high flow situations (Harmel et al., 2007) was beyond the scope of this simple error estimation, but for future studies the error interval could be estimated around a mean value for hydrological and isotope data to weight the uncertainty towards extreme values. In

5 contrast to Harmel et al.'s (2006) analysis of water quality, we did not find a significant statistical difference between the sample collection methods (Table 4). This suggests that even in a relatively small catchment $\left(2.3 \mathrm{~km}^{2}\right)$ where a sub-daily runoff response occurs, spot samples seem to adequately characterize the mean daily stream isotope composition, as long as sampled over sufficient long time periods.

\subsection{Model sensitivity and multi-criteria calibration}

Using multiple model performance measures (NS, VE and RMSE) and isotope data, in addition to flow data, for calibration and evaluation (Khu et al., 2008) of the CIM model was found to help identify and constrain behavioural parameter sets (Table 6). This is consistent with previous studies which used geochemical tracers in multi-calibration 15 of hydrological models (e.g. Balin, 2004; Birkel et al., 2009; Tetzlaff et al., 2008). Our basic calibration objectives are limited to the specific character of the performance measures. However, tracer and flow module parameters are uncorrelated in relation to their respective objective function. This means the isotope mixing volume parameters only affect the simulation of $\delta^{2} \mathrm{H}$ and vice versa, which allows calibration of the isotope module parameters to the specific performance measures for deuterium simulation (Fenicia et al., 2007). This highlights the advantages of multi-objective model calibration using tracers (Fenicia et al., 2008a).

Figure 6 shows that model parameters are well identifiable even if that depends to a certain degree on the objective function applied (Fenicia et al., 2008b). The isotope 25 mixing volume parameters were found to be less identifiable (Fig. 7) than the flow parameters due to a poorer performance of deuterium simulations. Hooper et al. (1988) found only one identifiable passive storage for the Birkenes model simulating conservative tracers in streamflow. However, the parameters are necessary to account for
HESSD

$6,6207-6246,2009$

Assessing the added value of

high-resolution isotope tracer data

C. Birkel et al.

Title Page

Abstract Introduction

Conclusions

Tables

References

Figures

14

$\rightarrow$

4

Back

Close

Full Screen / Esc

Printer-friendly Version

Interactive Discussion 
"old" water stored in the unsaturated zone prior to the event (cf. McGuire et al., 2006) to achieve sufficient damping in the stream response (Barnes and Bonell, 1996). The parameter space implies that better simulations are achieved for higher immobile mixing volumes (>effective porosity), which is consistent with thick soil and till layers and 5 underlying sandstones in the Wemyss catchment (Table 1). However, equifinality in the only two tracer parameters makes it impossible to determine catchment mixing volumes with any degree of certainty (Page et al., 2007). In general, a multi-objective calibration approach supports the value of tracer data in hydrological modelling (McGuire et al., 2006) despite the additional uncertainty introduced.

\section{Conclusions}

In this paper we have explored the added value of a daily precipitation and stream deuterium $\delta^{2} \mathrm{H}$ dataset in modelling the hydrological behaviour of a small agricultural catchment. A simple Catchment Isotope Model CIM has been applied and its performance assessed using multi-objective calibration incorporating model and measure15 ment uncertainty. The CIM model was able to simulate the runoff response with wellconstrained values for its parameters. The isotope module (two additional parameters) based on an assumption of "good mixing" was found to adequately reflect the system's response to extreme isotope input concentrations, but to average out between precipitation event dynamics. These dynamics in the isotope response can be seen

in the measured data even once uncertainty has been included and indicate a more variable catchment system in terms of mixing processes. The isotope parameters are insensitive suggesting equifinality, which precludes accurate determination of effective catchment mixing volumes and suggests a wide distribution of transit times for water in the catchment. This difficulty shown here has wider implications for the even more challenging task of simulating reactive tracers. However, the implementation of isotope data as an additional independent objective function into the calibration routine of the CIM model successfully constrained behavioural parameter sets and therefore

HESSD

6, 6207-6246, 2009

Assessing the added value of

high-resolution isotope tracer data

C. Birkel et al.

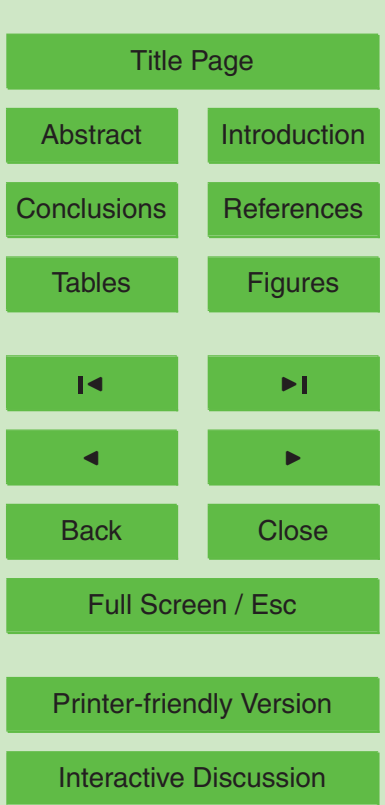


the model's degrees of freedom. The multi-criteria calibration was equally successful for the different output resolutions tested. It was also shown that the resolution of input data is important for the isotope model performance and it is recommended that sampling procedures should be designed to capture as much temporal variability 5 as possible. The high-resolution isotope data presented here, also allowed significant enhancement of the CIM model by conceptualizing a preferential flow path, which directly contributes to in-stream mixing. This process is not of importance for the flow module, but clearly improved the isotope simulation and would not have adequately been captured from weekly stream deuterium concentrations. Despite the introduc10 tion of additional uncertainty we therefore conclude that high-resolution isotope data is beneficial, especially for model conceptualization and calibration.

Acknowledgements. This work has been funded by a Macaulay Development Trust PhD studentship. We are grateful to F. Napier and B. McCreadie from the Scottish Environment Protection Agency (SEPA) and to the British Atmospheric Data Centre (BADC) for access to their data 15 and use of experimental facilities. The authors would like to thank the field team $\mathrm{H}$. Watson, C. Taylor, C. Abel and Y. Cook for their help. S. Gibbs helped processing water samples and J. Bacon, B. Thornton and L. Spezia contributed setting up a measurement protocol for the laser diode analyzer.

\section{References}

Balin, D.: Hydrological behaviour through experimental and modelling approaches: application to the Haute-Mentue catchment, PhD thesis 3007, Lausanne, Switzerland, 2004.

Barnes, C. J. and Bonell, M.: Application of unit hydrograph techniques to solute transport in catchments, Hydrol. Process., 10(6), 793-802, 1996.

Beven, K.: On under-mining the science, Hydrol. Process., 20, 3141-3146, 2006.

25 Birkel, C., Tetzlaff, D., Dunn, S. M., and Soulsby, C.: Towards simple dynamic process conceptualization in rainfall-runoff models using multi-criteria calibration and tracers in temperate, upland catchments, Hydrol. Processes., in press, 2009.

\section{HESSD}

6, 6207-6246, 2009

Assessing the added value of

high-resolution isotope tracer data

C. Birkel et al.

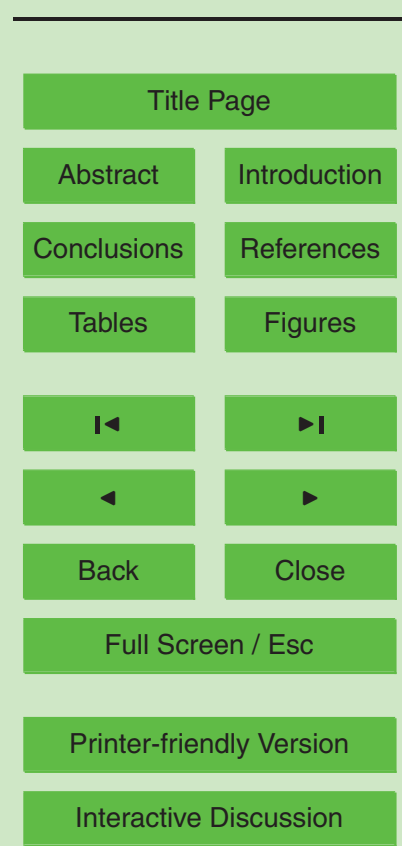


Criss, R. E. and Winston, W. E.: Do Nash values have value? Discussion and alternate proposals, Hydrol. Process., 22, 2723-2725, 2008.

De Grosbois, E., Hooper, R. P., and Christophersen, N.: A multisignal automatic calibration methodology for hydrochemical models - a case-study of the Birkenes model, Water Resour. Res., 24(8), 1299-1307, 1988.

Di Baldassarre, G. and Montanari, A.: Uncertainty in river discharge observations: a quantitative analysis, Hydrol. Earth Syst. Sci., 13, 913-921, 2009, http://www.hydrol-earth-syst-sci.net/13/913/2009/.

Dunn, S. M. and Mackay, R.: Spatial variation in evapotranspiration and the influence of land use on catchment hydrology, J. Hydrol., 171, 49-73, 1995.

Dunn, S. M., Freer, J., Weiler, M., Kirkby, M. J., Seibert, J., Quinn, P. F., Lischeid, G., Tetzlaff, D., and Soulsby, C.: Conceptualization in catchment modelling: simply learning? Hydrol. Process., 22, 2389-2393, doi:10.1002/hyp.7070.2008a, 2008.

Dunn, S. M., Bacon, J. R., Soulsby, C., Tetzlaff, D., Stutter, M., Waldron, S., and Malcolm, I. A.: Interpretation of homogeneity in $\mathrm{d}^{18} \mathrm{O}$ signatures of stream water in a nested sub-catchment system in north east Scotland, Hydrol. Process., 22, 4767-4782, doi:10.1002/hyp.7088, 2008b.

Dunn, S. M. and Bacon, J. R.: Assessing the value of $\mathrm{Cl}$ - and $\delta^{18} \mathrm{O}$ data in modelling the hydrological behaviour of a small upland catchment in northeast Scotland, Hydrol. Res., 20 39(5-6), 337-358, doi:10.2166/nh.2008.134, 2008.

Dunn, S. M., Birkel, C., Soulsby, C., and Tetzlaff, D.: Transit time distributions of a conceptual model: their characteristics and sensitivities, HP Ann. Rev., in review, 2009.

Fenicia, F., Savenije, H. H. G., Matgen, P., and Pfister, L.: A comparison of alternative multiobjective calibration strategies for hydrological modelling, Water Resour. Res., 43(W03434), 25 1-16, 2007.

Fenicia, F., Savenije, H. H. G., Matgen, P., and Pfister, L.: Understanding catchment behavior through stepwise model concept improvement, Water Resour. Res., 44(W01402), 1-13, doi:10.1029/2006WR005563, 2008a.

Fenicia, F., McDonnell, J. J., and Savenije, H. H. G.: Learning from model improvement: On the contribution of complementary data to process understanding, Water Resour. Res., 44, W06419, doi:10.1029/2007WR006386, 2008b.

Gupta, H. V., Wagener, T., and Liu, Y.: Reconciling theory with observations: elements of a diagnostic approach to model evaluation, Hydrol. Process., 22, 3802-3813,

\section{Assessing the added value of \\ high-resolution isotope tracer data}

C. Birkel et al.

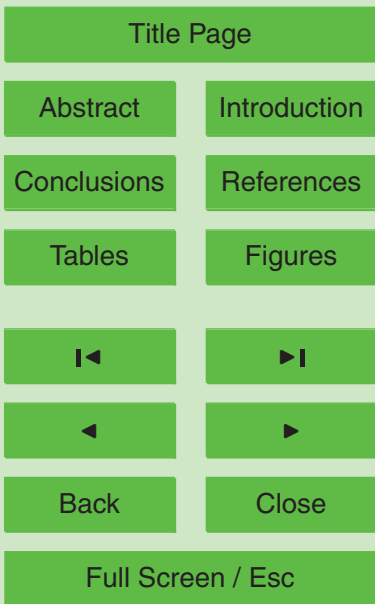

Printer-friendly Version

Interactive Discussion 
doi:10.1002/hyp.6989, 2008.

Harmel, R. D., Cooper, R. J., Slade, R. M., Haney, R. L., and Arnold, J. G.: Cumulative uncertainty in measured streamflow and water quality data for small watersheds, Am. Soc. Agr. Biol. Engi., 49(3), 689-701, 2006.

5 Harmel, R. D. and Smith, P. K.: Consideration of measurement uncertainty in the evaluation of goodness-of-fit in hydrologic and water quality modeling, J. Hydrol., 337, 326-336, doi:10.1016/j.jhydrol.2007.01.043, 2007.

Harmel, R. D., Smith, D. R., King, K. W., and Slade, R. M.: Estimating storm discharge and water quality data uncertainty: A software tool for monitoring and modeling applications,

10 Environ. Modell. Softw., 24, 832-842, 2009.

Herzer, H. and Kinzelbach, W.: Coupling of transport and chemical processes in numerical transport models, Proceedings of the International Conference on impact of physico chemistry on the study, design and optimization of processes in natural porous media (IMPACT), Nancy, France. 1987.

15 Hooper, R. P., Stone, A., Christophersen, N., de Grosbois, E., and Seip, H. M.: Assessing the Birkenes model of stream acidification using a multisignal calibration methodology, Water Resour. Res., 24(8), 1308-1316, 1988.

International Atomic Energy Agency: IAEA-WMO programme on isotopic composition of precipitation: Global network of isotopes in precipitation (GNIP) Technical procedure for sam-

20 pling. http://www-naweb.iaea.org/napc/ih/GNIP/userupdate/sampling.pdf, 2009.

Ivanovic, R. F. and Freer, J. E.: Science versus politics: truth and uncertainty in predictive modelling, Hydrol. Process., 23, 2549-2554, doi:10.1002/hyp.7406, 2009.

Katsuyama, M., Kabeya, N., and Ohte, N.: Elucidation of the relationship between geographic and time sources of stream water using a tracer approach in a headwater catchment, Water Resour. Res., 45, W06414, doi:10.1029/2008WR007458, 2009.

Khu, S. T., Madsen, H., and di Pierro, F.: Incorporating multiple observations for distributed hydrologic model calibration: An approach using a multi-objective evolutionary algorithm and clustering, Adv. Water Resour., 31, 1387-1398, 2008.

Leaney, F. W., Smettem, K. R. J., and Chittleborough, D. J.: Estimating the contribution of preferential flow to subsurface runoff from a hillslope using deuterium and chloride, J. Hydrol., 147(1-4), 83-103, 1993.

Lis, G., Wassenaar, L. I., and Hendry, M. J.: High-precision laser spectroscopy D/H and ${ }^{18} \mathrm{O} /{ }^{16} \mathrm{O}$ measurements of microliter natural water samples, Anal. Chem., 80, 287-293, 2008.
HESSD

6, 6207-6246, 2009

Assessing the added value of

high-resolution

isotope tracer data

C. Birkel et al.

\section{Title Page}

Abstract

Introduction

Conclusions

Tables

References

Figures

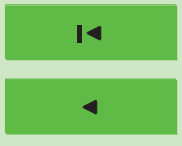

$\rightarrow$ I

Back

Close

Full Screen / Esc

Printer-friendly Version

Interactive Discussion 
Liu, Y., Freer, F., Beven, K., and Matgen, P.: Towards a limits of acceptability approach to the calibration of hydrological models: Extending observation error, J. Hydrol., 367, 93-103, doi:10.1016/j.jhydrol.2009.01.016, 2009.

Lyon, S. W., Desilets, S. L. E., and Troch, P. A.: A tale of two isotopes: differences in hydrograph 5 separation for a runoff event when using $d \mathrm{D}$ versus $d^{18} \mathrm{O}$, Hydrol. Process., 23, 2095-2101, doi:10.1002/hyp.7326, 2009.

Maloszewski, P. and Zuber, A.: Determining the turnover time of groundwater systems with the aid of environmental tracers: 1. Models and their applicability, J. Hydrol., 57, 207-231, doi:10.1016/0022-1694(82)90147-0, 1982.

10 McDonnell, J. J., Stewart, M. K., and Owens, I. F.: Effect of catchment-scale subsurface mixing on stream isotopic response, Water Resour. Res., 27, 3065-3073, 1991.

McGuire, K. J., Weiler, M., and McDonnell, J. J.: Integrating tracer experiments with modeling to assess runoff processes and water transit times, Adv. Water Resour., 30, 824-837, doi:10.1016/j.advwatres.2006.07.004, 2006.

15 Moss, M. E.: Some basic considerations in the design of hydrologic data networks, Water Resour. Res., 15, 1673-1676, 1979.

Nash, J. E. and Sutcliffe, J. V.: River flow forecasting through conceptual models, 1. A discussion of principles, J. Hydrol., 10, 282-290, 1970.

Ó Dochartaigh, B. E.: Hydrogeology of the Devonian Aquifer in Strathmore, Groundwater Systems and Water Quality Programme, Internal Report IR/04/130R, British Geological Society, Nottingham, UK, 2004.

Page,T., Beven, K. J., Freer, J., and Neal, C.: Modelling the chloride signal at Plynlimon, Wales, using a modified dynamic TOPMODEL incorporating conservative chemical mixing (with uncertainty), Hydrol. Process. 21, 292-307, doi:10.1002/hyp.6186, 2007.

25 Pappenberger, F. and Beven, K. J.: Ignorance is bliss: 7 reasons not to use uncertainty analysis, Water Resour. Res., 42(5), W05302, doi:10.1029/2005W05302, 2006.

Pearce, A. J., Stewart, M. K., and Sklash, M. G.: Storm runoff generation in humid headwater catchments. 1. Where does the water come from, Water Resour. Res., 22, 1263-1272, 1986.

Sayama, T. and McDonnell, J. J.: A new time-space accounting scheme to predict stream water 30 residence time and hydrograph source components at the watershed scale, Water Resour. Res., 45, W07401, doi:10.1029/2008WR007549, 2009.

Scottish Environment Protection Agency: Eutrophication assessment of Scottish Coastal, Estuarine and Inland Waters, 2005, www.sepa.org.uk/scotlands_environment/data_and_reports/

HESSD

6, 6207-6246, 2009

Assessing the added value of

high-resolution isotope tracer data

C. Birkel et al.

Title Page

Abstract

Introduction

Conclusions

References

Tables

Figures

14

$\triangleleft$

Back

Full Screen / Esc

Printer-friendly Version

Interactive Discussion 
scientific_and_technical.aspx.

Seibert, J., Rodhe, A., and Bishop, K.: Simulating interactions between saturated and unsaturated storage in a conceptual runoff model, Hydrol. Process., 17(2), 379-90, 2003.

Simic, E. and Destouni, G.: Water and solute residence times in a catchment: stochasticmechanistic model interpretation of ${ }^{18} \mathrm{O}$ transport, Water Resour. Res., 35, 2109-19, 1999.

Soulsby, C., Malcolm, R., Helliwell, R. C., Ferrier, R. C., and Jenkins, A.: Isotope hydrology of the Allt a' Mharcaidh catchment, Cairngorm mountains, Scotland: implications for hydrological pathways and water residence times, Hydrol. Process., 14, 747-762, 2000.

Soulsby, C., Rodgers, P., Dawson, J., and Dunn, S. M.: A tracer-based assessment of hydrological pathways at different spatial scales in a mesoscale Scottish catchment, Hydrol. Process., 17, 759-777, doi:10.1002/hyp.1163, 2003.

Soulsby, C., Tetzlaff, D., Rodgers, P., Dunn, S., and Waldron, S.: Runoff processes, streamwater residence times and controlling landscape characteristics in a mesoscale catchment: an initial assessment, J. Hydrol., 325, 197-221, 2006.

15 Soulsby, C. and Tetzlaff, D.: Towards simple approaches for mean residence time estimation in ungauged basins using tracers and soil distributions, J. Hydrol., 363(1-4), 60-74, 2008.

Soulsby, C., Neal, C., Laudon, H., Burns, D. A., Merot, P., Bonell, M., Dunn, S. M., and Tetzlaff, D.: Catchment data for process conceptualization: simply not enough? Hydrol. Process., 22, 2057-2061, 2008.

20 Stadnyk, T., St Amour, N., Kouwen, N., Edwards, T. W. D., Pietroniro, A., and Gibson, J. J.: A groundwater separation study in boreal wetland terrain: The WATFLOOD hydrological model compared with stable isotope tracers, Isotop. Environ. Health Stud., 41(1), 49-68, 2005.

Stewart, M. K. and McDonnell, J. J.: Modelling base flow soil residence times from deuterium concentrations, Water Resour. Res., 27, 2681-2693, 1991.

Tetzlaff, D., Waldron, S., Brewer, M. J., and Soulsby, C.: Assessing nested hydrological and hydrochemical behaviour of a mesoscale catchment using continuous tracer data, J. Hydrol., 336, 430-443, 2007a.

Tetzlaff, D., Soulsby, C., Waldron, S., Malcolm, I. A., Bacon, P. J., Dunn, S. M., and Lilly, A.: Conceptualisation of runoff processes using GIS and tracers in a nested mesoscale catchment, Hydrol. Process., 21, 1289-1307, 2007b.

Tetzlaff, D., Uhlenbrook, S., Eppert, S., and Soulsby, C.: Does the incorporation of process conceptualization and tracer data improve the structure and performance of a simple
HESSD

6, 6207-6246, 2009

Assessing the added value of

high-resolution isotope tracer data

C. Birkel et al.

\section{Title Page}

Abstract

Introduction

Conclusions

Tables

References

Figures

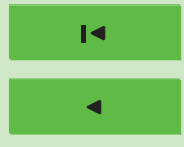

$\rightarrow$

Back

Close

Full Screen / Esc

Printer-friendly Version

Interactive Discussion 
rainfall-runoff model in a Scottish mesoscale catchment? Hydrol. Process., 22, 2461-2474, doi:10.1002/hyp.6841, 2008a.

Tetzlaff, D. and Soulsby, C.: Sources of baseflow in large catchments - using tracers to develop a holistic understanding of runoff generation, J. Hydrol., 359, 287-302, $2008 \mathrm{~b}$.

5 Turner, J., Albrechtsen, H. J., Bonell, M., Duguet, J. P., Harris, B., Meckenstock, R., McGuire, K., Moussa, R., Peters, N., Richnow, H. H., Sherwood-Lollar, B., Uhlenbrook, S., and van Lanen, $\mathrm{H}$.: Future trends in transport and fate of diffuse contaminants in catchments, with special emphasis on stable isotope applications, Hydrol. Process., 20, 205-213, doi:10.1002/hyp.6074, 2006.

10 Weiler, M., McGlynn, B. L.,. McGuire, K. J., and McDonnell, J. J.: How does rainfall become runoff? A combined tracer and runoff transfer function approach, Water Resour. Res., 39(11), 1315, doi:10.1029/2003WR002331, 2003.

Weiler, M. and McDonnell, J. J.: Conceptualizing lateral preferential flow and flow networks and simulating the effects on gauged and ungauged hillslopes, Water Resour. Res., 43, W03403, doi:10.1029/2006WR004867, 2007.

Wissmeier, L. and Uhlenbrook, S.: Distributed, high-resolution modelling of ${ }^{18} \mathrm{O}$ signals in a meso-scale catchment, J. Hydrol., 332(3-4), 497-510, 2007.

HESSD

6, 6207-6246, 2009

Assessing the added value of

high-resolution isotope tracer data

C. Birkel et al.

\section{Title Page}

Abstract

Conclusions

Tables

14

4

Back
Introduction

References

Figures

$\rightarrow$ I

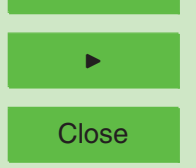

Full Screen / Esc
Printer-friendly Version

Interactive Discussion 


\section{HESSD}

6, 6207-6246, 2009

Table 1. Topographic, geologic, soil and land use descriptors of the Wemyss study catchment.

\begin{tabular}{|c|c|}
\hline Area $\left(\mathrm{km}^{2}\right)$ & $\begin{array}{c}\text { WEMYSS } \\
2.3\end{array}$ \\
\hline \multicolumn{2}{|l|}{ Topography } \\
\hline Mean elevation (m a.s.I.) & 134.7 \\
\hline Min. elevation (m a.s.I.) & 66 \\
\hline Max. elevation (m a.s.I.) & 250.9 \\
\hline Mean slope $\left({ }^{\circ}\right)$ & 8.8 \\
\hline Max. slope $\left({ }^{\circ}\right)$ & 45 \\
\hline $\begin{array}{l}\text { Drainage density }\left(\mathrm{km} / \mathrm{km}^{2}\right) \\
\text { Bedrock geology }\end{array}$ & 0.76 \\
\hline \multicolumn{2}{|l|}{ Superficial geology } \\
\hline Till (Diamicton) (\%) & 100 \\
\hline \multicolumn{2}{|l|}{ Landcover } \\
\hline Forest (\%) & 8.8 \\
\hline Grassland (\%) & 30.4 \\
\hline Agriculture (\%) & 56.5 \\
\hline Heather (\%) & I \\
\hline Buildings (\%) & 4.3 \\
\hline \multicolumn{2}{|l|}{ Soils } \\
\hline Humus iron podzol (\%) & 100 \\
\hline
\end{tabular}

\section{Assessing the added} value of

high-resolution isotope tracer data

C. Birkel et al.

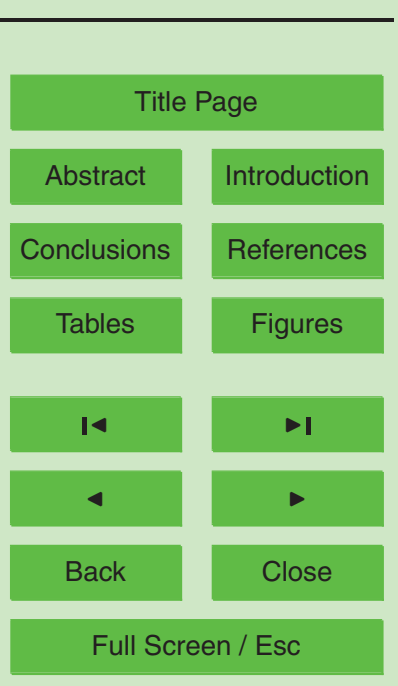

Printer-friendly Version

Interactive Discussion 


\section{HESSD}

6, 6207-6246, 2009

Table 2. Equations used to develop the Catchment Isotope Model (CIM).

\begin{tabular}{|c|c|c|c|}
\hline Variable & Equation & Parameters & Number \\
\hline Effective rain & $\begin{array}{l}P_{\text {eff }}(t)=P(t)-\mathrm{ET}(t) \\
\text { if } P>\mathrm{ET}\end{array}$ & $\begin{array}{l}P(t)=\text { precipitation }\left(\mathrm{mm} \mathrm{d}^{-1}\right) \\
\text { ET }(t)=\text { evapotranspiration } \\
\left(\mathrm{mm} \mathrm{d}^{-1}\right)\end{array}$ & Eq. (5) \\
\hline Effective evapotranspiration & $\begin{array}{l}\mathrm{ET}_{\text {eff }}(t)=\mathrm{ET}(t)-P_{\text {eff }}(t) \\
\text { if } \mathrm{ET}>P\end{array}$ & & Eq. (6) \\
\hline GWloss & GWloss $(t)=S_{\text {up }} * k$ & $\begin{array}{l}S_{\text {up }}=\text { upper storage volume } \\
(\mathrm{mm}) ; k=\text { rate parameter }\left(\mathrm{d}^{-1}\right) ;\end{array}$ & Eq. (7) \\
\hline $\begin{array}{l}\text { Linear reservoir outflow } \\
\text { Storage }\end{array}$ & $\begin{array}{l}Q(t)=S_{\mathrm{up}} \times k \\
S_{\mathrm{up}}=\left(S_{t-1}+P_{\mathrm{eff}}(t)\right)-\left(\mathrm{ET}_{\mathrm{eff}}(t)+Q(t)\right)\end{array}$ & $Q(t)=$ discharge $\left(\mathrm{mm} \mathrm{d}^{-1}\right)$ & $\begin{array}{l}\text { Eq. (8) } \\
\text { Eq. (9) }\end{array}$ \\
\hline Recharge & $R(t)=S_{\mathrm{up}} \times R$ & $R=$ rate parameter $\left(\mathrm{d}^{-1}\right)$ & Eq. (10) \\
\hline Streamflow & $Q_{\text {total }}(t)=Q_{\text {up }}(t)+Q_{1}(t)$ & $\begin{array}{l}Q_{\text {total }}(t)=\text { streamflow }\left(\mathrm{mm} \mathrm{d}^{-1}\right) \\
Q_{\text {up }}(t)=\text { upper storage outflow } \\
\left(\mathrm{mm} \mathrm{d}^{-1}\right) \\
Q_{\mid}(t)=\text { lower outflow }\left(\mathrm{mm} \mathrm{d}^{-1}\right)\end{array}$ & Eq. (11) \\
\hline Tracer input & $S=\left(S_{t-1}-Q_{t-1}\right)+N(t)$ & $N(i)=$ tracer input $(\% \circ)$ & Eq. (12) \\
\hline Storage mixing volume & $S=S_{\text {up }}+S_{M V}$ & $\begin{array}{l}S_{M V}=\text { additional mixing volume } \\
\text { upper storage }(\mathrm{mm})\end{array}$ & Eq. (13) \\
\hline Tracer outflow & $C Q(t)=(Q(t) * C S(t)) / S$ & $\begin{array}{l}C Q(t)=\text { discharging tracer con- } \\
\text { centration }(\%) ; C S(t)=\text { tracer con- } \\
\text { centration in storage }(\% \circ) \text {; }\end{array}$ & Eq. (14) \\
\hline Stream tracer concentration & $\begin{array}{l}C Q_{\text {total }}(t)=\left[\left(C Q_{\text {up }}(t) * Q_{\text {up }}(t)\right)\right. \\
\left.+\left(C Q_{1}(t) * Q_{1}(t)\right)\right] / Q_{\text {total }}(t)\end{array}$ & $\begin{array}{l}C Q_{\text {total }}(t)=\text { total stream concentra- } \\
\text { tion }(\% \circ) ; C Q_{\mathrm{up}}(t)=\text { upper storage } \\
\text { tracer outflow }(\% \circ) ; C Q_{1}(t)=\text { lower } \\
\text { storage tracer outflow }(\% \circ) ;\end{array}$ & Eq. (15) \\
\hline
\end{tabular}

Assessing the added value of high-resolution isotope tracer data

C. Birkel et al.

Title Page

Abstract Introduction

Conclusions

References

Tables

Figures

14

Back

Full Screen / Esc

Printer-friendly Version

Interactive Discussion 


\section{HESSD}

6, 6207-6246, 2009

\section{Assessing the added value of \\ high-resolution isotope tracer data}

C. Birkel et al.

Table 3. Wemyss daily and weekly statistics for deuterium $\delta^{2} \mathrm{H}$ in stream $(Q)$ and precipitation $(P)$ water.

\begin{tabular}{lllllll}
\hline Daily $\delta^{2} \mathrm{H}$ & Mean & Min & Max & Std. dev. & 90th percentile & 10th percentile \\
\hline$Q$ Wemyss & -53.18 & -79.69 & -30.79 & 5.58 & -48.84 & -57.37 \\
$P$ & -45.76 & -151.02 & 2.77 & 29.42 & -14.75 & -87.61 \\
Weekly $\delta^{2} \mathrm{H}$ & & & & & & \\
$Q$ Wemyss & -53.36 & -72.11 & -43.21 & 5.29 & -48.51 & -57.75 \\
$P$ & -49.57 & -134.42 & -4.71 & 28.53 & -19.17 & -89.32 \\
\hline
\end{tabular}

Title Page

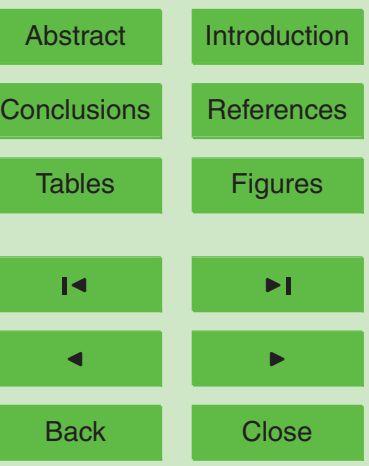

Full Screen / Esc

Printer-friendly Version

Interactive Discussion 


\section{HESSD}

6, 6207-6246, 2009

\section{Assessing the added value of \\ high-resolution isotope tracer data}

C. Birkel et al.

Table 4. Weekly stream composite and grab samples for the same period of time at Wemyss.

\begin{tabular}{lllllllll}
\hline & Mean & Min & Max & Std. dev. & 90th percentile & 10th percentile & Kurtosis & Skew \\
\hline Composite $\delta^{2} \mathrm{H}$ samples & -53.36 & -72.11 & -43.21 & 5.29 & -48.51 & -57.75 & 3.56 & 3.6 \\
Grab $\delta^{2} \mathrm{H}$ samples & -53.35 & -71.06 & -41.03 & 5.17 & -48.79 & -57.60 & 5.18 & 3.69 \\
\hline
\end{tabular}

Title Page

Abstract Introduction

Conclusions

References

Tables

Figures

14

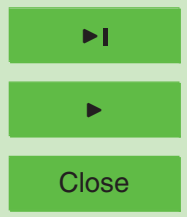

Back

Full Screen / Esc

Printer-friendly Version

Interactive Discussion 


\section{HESSD}

6, 6207-6246, 2009

\section{Assessing the added value of \\ high-resolution isotope tracer data}

C. Birkel et al.

Table 5. Performance statistics for discharge (Q_NS, Q_VE, and Q_RMSE) and deuterium (D_NS, D_VE, and D_RMSE) simulation applying different model parameterizations (5 to 7 parameters) under measurement uncertainty.

\begin{tabular}{lllllll}
\hline \multirow{2}{*}{ Model } & \multicolumn{2}{l}{ Discharge Q } & & Deuterium D & \\
& Q_NS & Q_VE & Q_RMSE & D_NS & D_VE & D_RMSE \\
\hline 5-Par CIM & 0.72 & 0.51 & 0.43 & 0.43 & 0.96 & 2.32 \\
6-Par CIM & 0.86 & 0.64 & 0.33 & 0.45 & 0.97 & 2.26 \\
7-Par CIM & 0.87 & 0.64 & 0.32 & 0.54 & 0.98 & 2.06 \\
\hline
\end{tabular}

Title Page

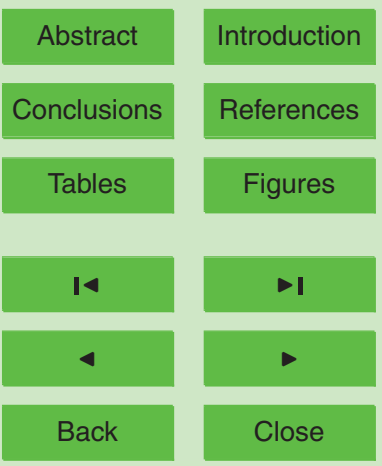

Full Screen / Esc

Printer-friendly Version

Interactive Discussion 


\section{HESSD}

6, 6207-6246, 2009

\section{Assessing the added value of \\ high-resolution isotope tracer data}

Table 6. Initial, multi-mode and multi-criteria calibrated behavioural parameter range applied with the seven-parameter CIM model.

\begin{tabular}{|c|c|c|c|c|c|c|}
\hline \multirow[b]{2}{*}{ Parameter } & \multicolumn{2}{|c|}{ Initial parameter range } & \multicolumn{2}{|c|}{$\begin{array}{l}\text { Multi-mode calibrated } \\
\text { parameter range (flow model) }\end{array}$} & \multicolumn{2}{|c|}{$\begin{array}{l}\text { Multi-criteria modes and measures calibrated } \\
\text { parameter range (flow-tracer model) }\end{array}$} \\
\hline & $\min$ & $\max$ & $\min$ & $\max$ & $\min$ & $\max$ \\
\hline$k_{2}\left(\mathrm{~d}^{-1}\right)$ & 0 & 1 & 0.001 & 0.15 & 0.03 & 0.04 \\
\hline$R\left(\mathrm{~d}^{-1}\right)$ & 0 & 1 & 0.12 & 0.42 & 0.27 & 0.4 \\
\hline$c\left(\mathrm{~d}^{-1}\right)$ & 0 & 1 & 0.001 & 0.3 & 0.03 & 0.08 \\
\hline$S_{M V}(\mathrm{~mm})$ & 0 & 1000 & - & - & 180 & 450 \\
\hline$V_{M V}(\mathrm{~mm})$ & 0 & 1000 & - & - & 500 & 950 \\
\hline
\end{tabular}

C. Birkel et al.

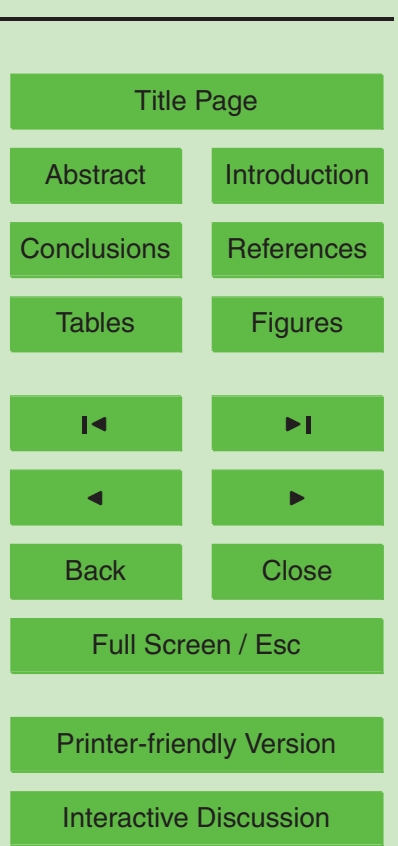




\section{HESSD}

6, 6207-6246, 2009

\section{Assessing the added value of \\ high-resolution isotope tracer data}

C. Birkel et al.

Table 7. Performance statistics (D_NS, D_VE, and D_RMSE) for deuterium simulation applying different input function resolutions.

\begin{tabular}{lccc}
\hline 7-PAR CIM & D_NS & D_VE & D_RMSE \\
\hline Daily input & 0.54 & 0.98 & 2.06 \\
Weekly input & 0.51 & 0.97 & 2.09 \\
Bi-weekly input & 0.45 & 0.97 & 2.24 \\
\hline
\end{tabular}

Title Page

Abstract

Conclusions

Tables

14

4

Back

Full Screen / Esc

Printer-friendly Version

Interactive Discussion 

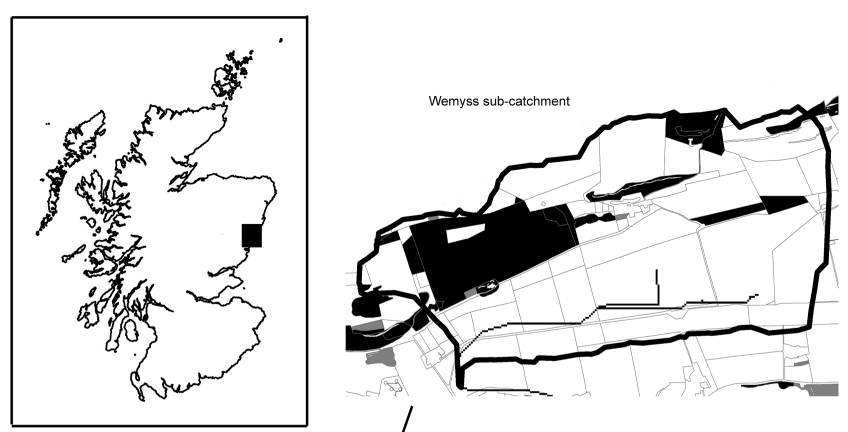

Land use

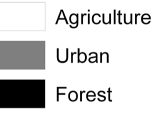

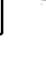

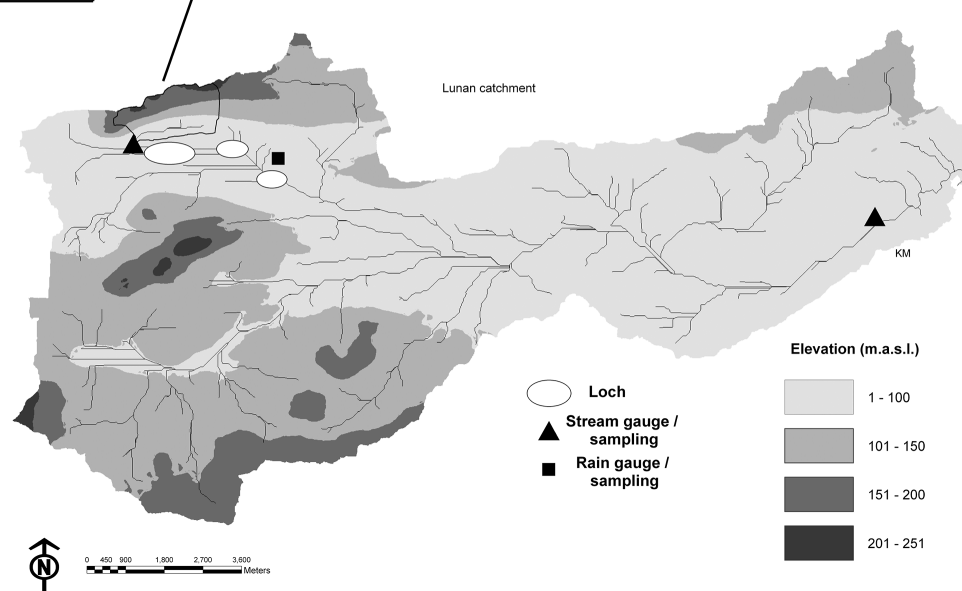

Fig. 1. Topography and land use of the Wemyss sub-catchment with reference to the Lunan catchment.

\section{HESSD}

6, 6207-6246, 2009

Assessing the added value of

high-resolution isotope tracer data

C. Birkel et al.

Title Page

Abstract

Introduction

Conclusions

References

Tables

Figures

14

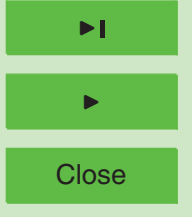

Back

Full Screen / Esc

Printer-friendly Version

Interactive Discussion 


\section{HESSD}

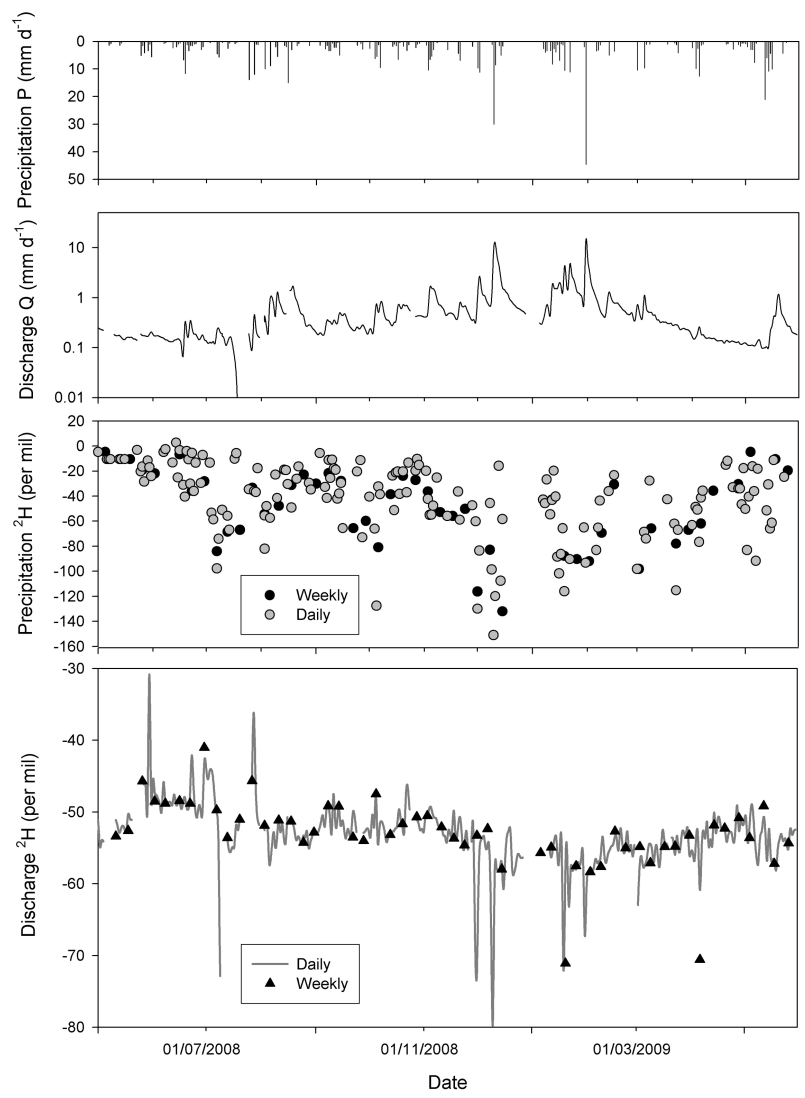

6, 6207-6246, 2009

Assessing the added value of

high-resolution isotope tracer data

C. Birkel et al.

Title Page

Abstract

Introduction

Conclusions

References

Tables

Figures

14

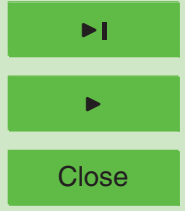

Back

Full Screen / Esc

Fig. 2. Daily hydrological (precipitation $P$ and discharge $Q$ ) and daily and weekly deuterium isotopes $\left(\delta^{2} H\right)$ in $P$ and $Q$ for the study period (1 May 2008-31 May 2009) at Wemyss.

Printer-friendly Version

Interactive Discussion 


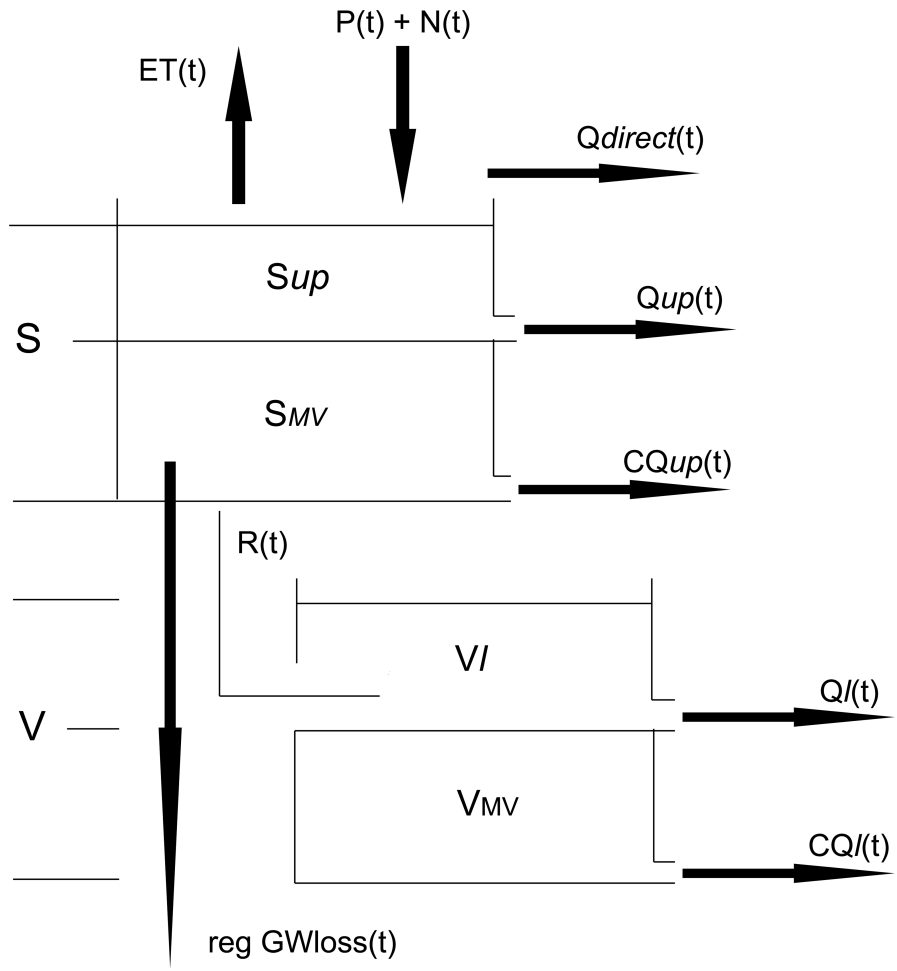

$\mathrm{P}(\mathrm{t})$...Precipitation

S, V...Storage volumes

$R(t)$...Recharge

$\mathrm{Q}(\mathrm{t})$...Discharge

$\mathrm{CQ}(\mathrm{t})$...Discharging tracer
ET(t)...Evapotranspiration

$\mathrm{N}(\mathrm{t})$... Tracer input

Qdirect $(\mathrm{t})$...Direct discharge reg GWloss(t)...Regional

groundwater recharge

\section{HESSD}

6, 6207-6246, 2009

Assessing the added value of

high-resolution isotope tracer data

C. Birkel et al.

Title Page

Abstract

Introduction

Conclusions

References

Tables

Figures

14

$\rightarrow$ I

4

Back

Close

Full Screen / Esc

Printer-friendly Version

Interactive Discussion 


\section{HESSD}

6, 6207-6246, 2009

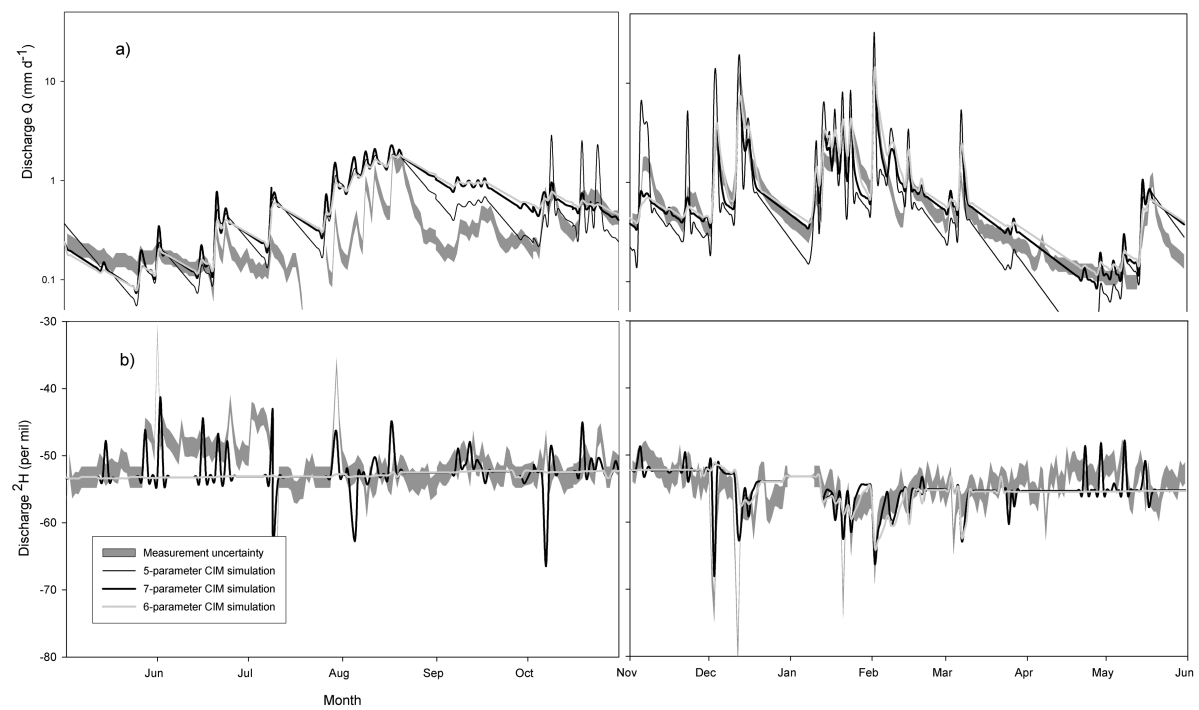

Assessing the added value of

high-resolution isotope tracer data

C. Birkel et al.

Title Page

Abstract Introduction

Conclusions

References

Tables

Figures

14

$\rightarrow$ I

4

Back

Close

Full Screen / Esc

Printer-friendly Version

Interactive Discussion 


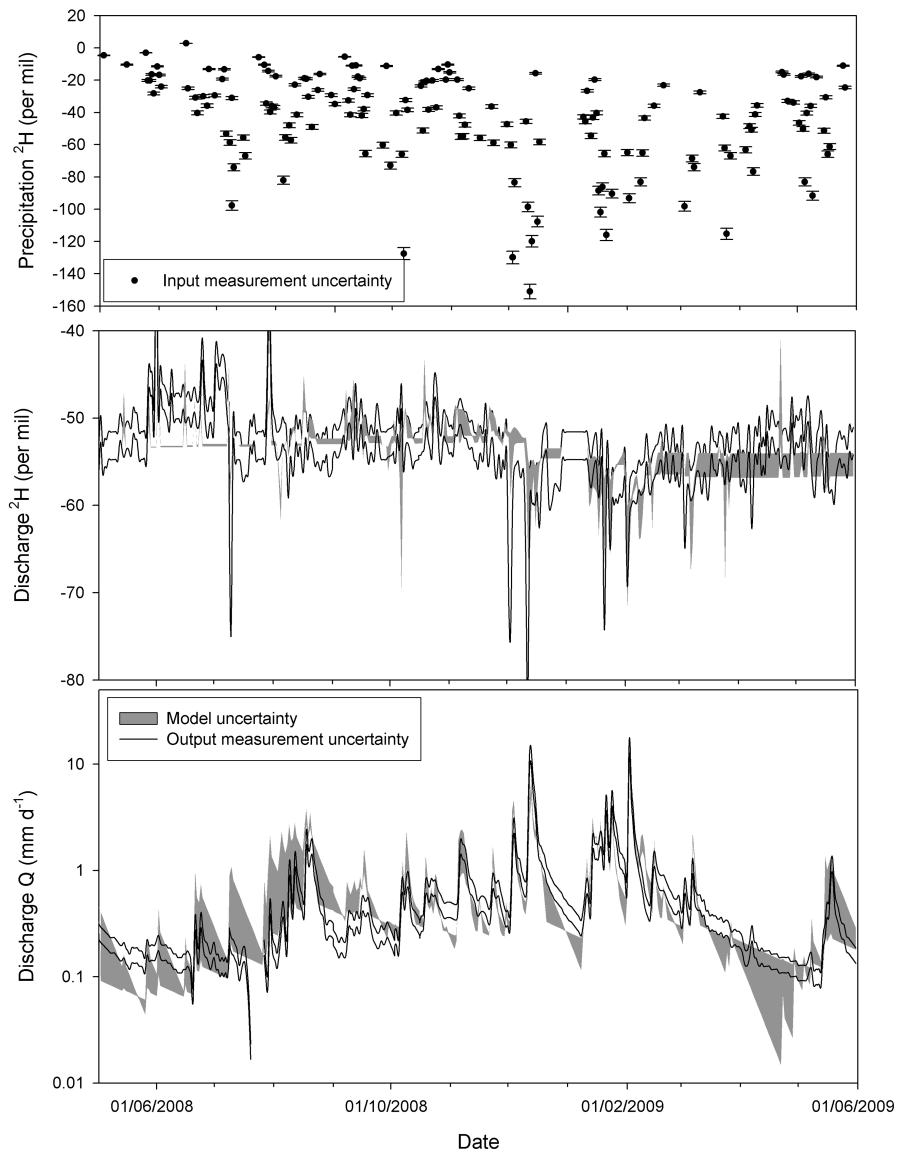

HESSD

6, 6207-6246, 2009

Assessing the added value of

high-resolution isotope tracer data

C. Birkel et al.

Title Page

Abstract

Introduction

Conclusions

References

Tables

Figures

14

$>1$

4

Back

Close

Full Screen / Esc

Fig. 5. Combined data input, output and model uncertainty.

Printer-friendly Version

Interactive Discussion 

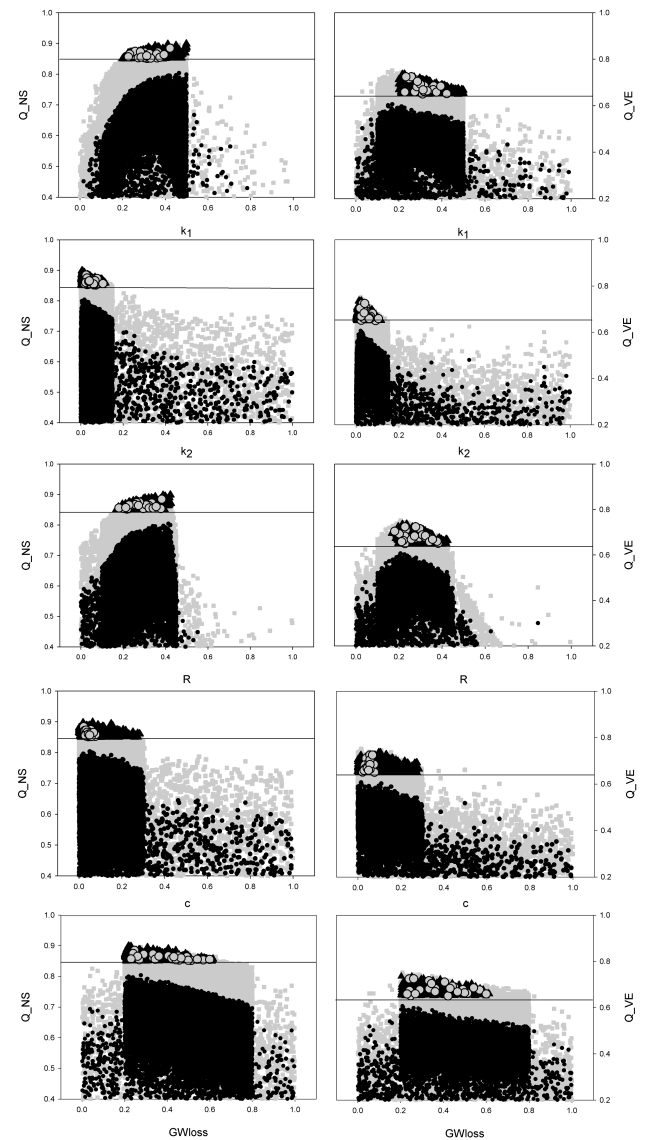

GWloss

Fig. 6. Flow module parameter sampling space testing sensitivity and defining behavioural threshold values (lines) for model calibration. Black triangles above threshold indicate the multi modes calibration of the flow model. The grey circles above threshold show the multi-criteria calibrated flow-tracer CIM model under measurement uncertainty.

\section{HESSD}

6, 6207-6246, 2009

Assessing the added value of

high-resolution isotope tracer data

C. Birkel et al.

Title Page

Abstract

Conclusions

\section{Tables}

14

4

Back

Full Screen / Esc

Printer-friendly Version 


\section{HESSD}

6, 6207-6246, 2009
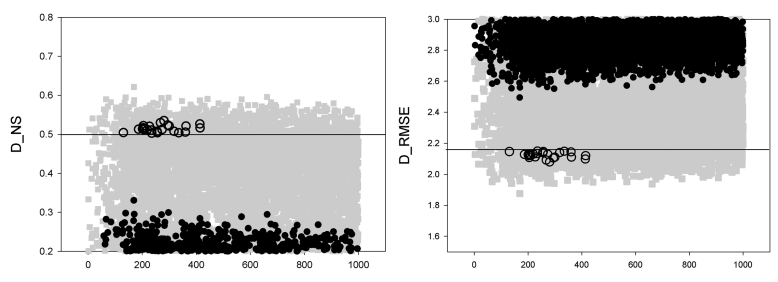

$S_{M V}$

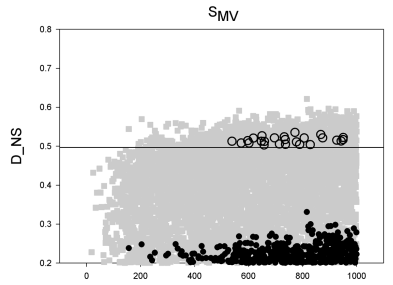

$\mathrm{V}_{\mathrm{MV}}$

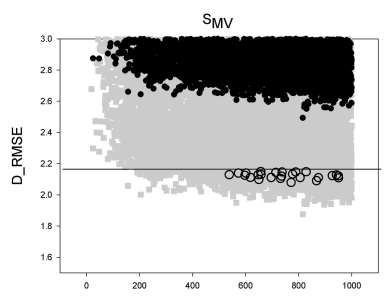

$\mathrm{V}_{\mathrm{MV}}$

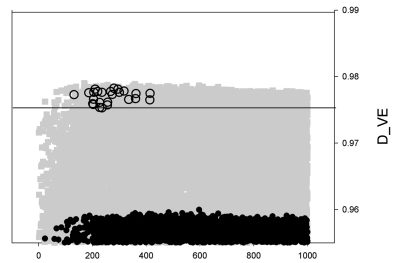

$\mathrm{s}_{\mathrm{MV}}$

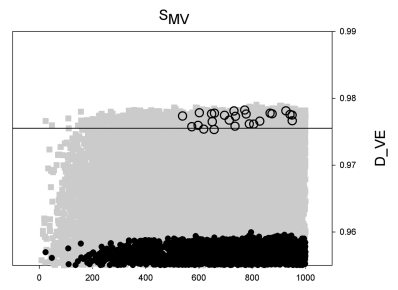

$\mathrm{V}_{\mathrm{MV}}$

Uncertain parameter space

- Parameter space

- Mutti-criteria callibrated parameter sets

Fig. 7. Sensitivity of mixing volume parameters $\left(S_{M V}\right.$ and $\left.V_{M V}\right)$ and the definition of threshold values (lines) for multi-criteria calibration (black circles above threshold) of the flow tracer CIM model under measurement uncertainty.

\section{Assessing the added value of \\ high-resolution isotope tracer data}

C. Birkel et al.

Title Page

Abstract

Introduction

Conclusions

References

Tables

Figures

14

$>$ I

4

Back

Close

Full Screen / Esc

Printer-friendly Version

Interactive Discussion 


\section{HESSD}

6, 6207-6246, 2009

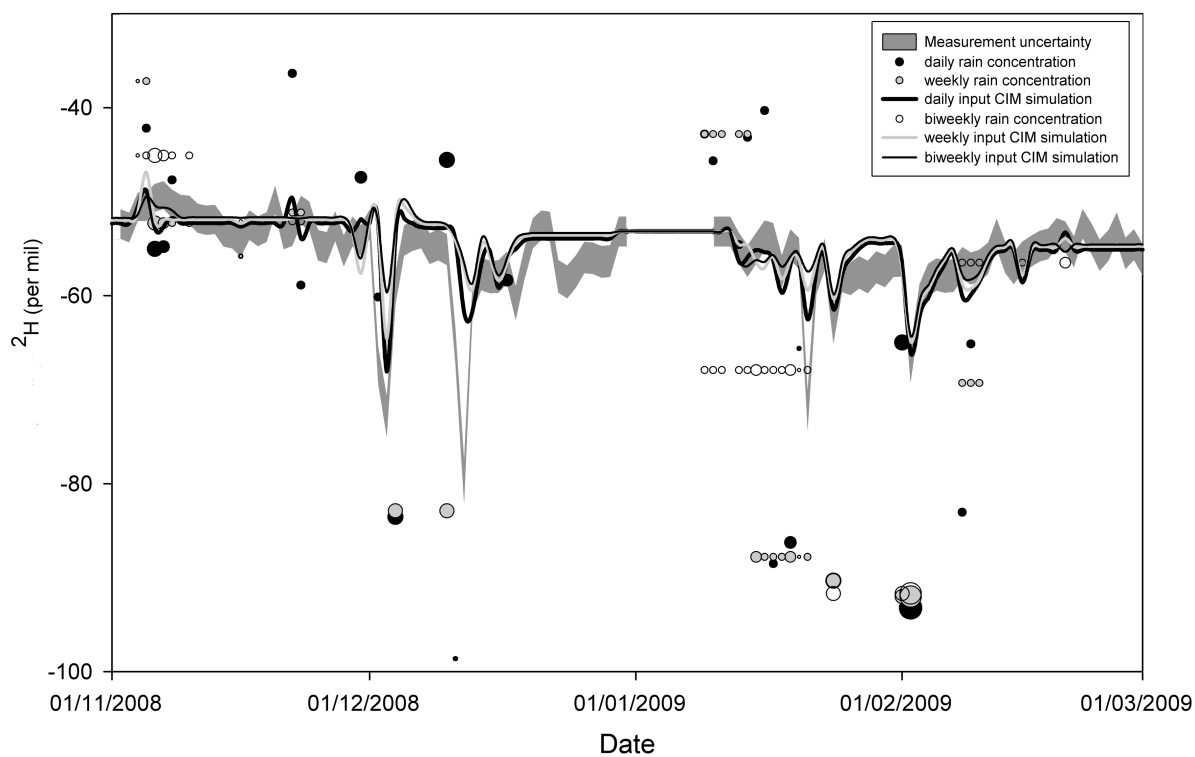

Fig. 8. Effect of different input sampling resolutions (daily, weekly and bi-weekly) on multicriteria calibrated 7-parameter CIM stream deuterium simulation. Shown for the winter and spring period 1 November 2008-1 March 2009.

\section{Assessing the added value of \\ high-resolution isotope tracer data}

C. Birkel et al.

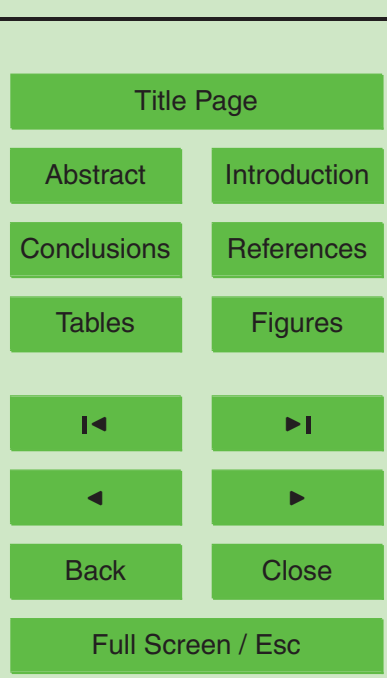

Printer-friendly Version

Interactive Discussion 